Geological Society, London, Special Publications

Palaeoproterozoic supercontinents and global evolution: correlations from core to atmosphere

S. M. Reddy and D. A. D. Evans

Geological Society, London, Special Publications 2009; v. 323; p. 1-26 doi:10.1144/SP323.1

Email alerting service

Permission request

Subscribe click here to receive free email alerts when new articles cite this article

click here to seek permission to re-use all or part of this article

click here to subscribe to Geological Society, London, Special Publications or the Lyell Collection

Notes

Downloaded by on 10 September 2009 


\title{
Palaeoproterozoic supercontinents and global evolution: correlations from core to atmosphere
}

\author{
S. M. REDDY ${ }^{1 *} \&$ D. A. D. EVANS ${ }^{2}$ \\ ${ }^{1}$ The Institute for Geoscience Research, Department of Applied Geology, Curtin University \\ of Technology, GPO Box U 1987, Perth, WA 6845, Australia \\ ${ }^{2}$ Department of Geology and Geophysics, Yale University, New Haven, CT 06520-8109, USA \\ *Corresponding author (e-mail: S.Reddy@curtin.edu.au)
}

\begin{abstract}
The Palaeoproterozoic era was a time of profound change in Earth evolution and represented perhaps the first supercontinent cycle, from the amalgamation and dispersal of a possible Neoarchaean supercontinent to the formation of the 1.9-1.8 Ga supercontinent Nuna. This supercontinent cycle, although currently lacking in palaeogeographic detail, can in principle provide a contextual framework to investigate the relationships between deep-Earth and surface processes. In this article, we graphically summarize secular evolution from the Earth's core to its atmosphere, from the Neoarchaean to the Mesoproterozoic eras (specifically $3.0-1.2 \mathrm{Ga}$ ), to reveal intriguing temporal relationships across the various 'spheres' of the Earth system. At the broadest level our compilation confirms an important deep-Earth event at $c .2 .7 \mathrm{Ga}$ that is manifested in an abrupt increase in geodynamo palaeointensity, a peak in the global record of large igneous provinces, and a broad maximum in several mantle-depletion proxies. Temporal coincidence with juvenile continental crust production and orogenic gold, massive-sulphide and porphyry copper deposits, indicate enhanced mantle convection linked to a series of mantle plumes and/or slab avalanches. The subsequent stabilization of cratonic lithosphere, the possible development of Earth's first supercontinent and the emergence of the continents led to a changing surface environment in which voluminous banded iron-formations could accumulate on the continental margins and photosynthetic life could flourish. This in turn led to irreversible atmospheric oxidation at 2.4-2.3 Ga, extreme events in global carbon cycling, and the possible dissipation of a former methane greenhouse atmosphere that resulted in extensive Palaeoproterozoic ice ages. Following the great oxidation event, shallow marine sulphate levels rose, sediment-hosted and iron-oxide-rich metal deposits became abundant, and the transition to sulphide-stratified oceans provided the environment for early eukaryotic evolution. Recent advances in the geochronology of the global stratigraphic record have made these inferences possible. Frontiers for future research include more refined modelling of Earth's thermal and geodynamic evolution, palaeomagnetic studies of geodynamo intensity and continental motions, further geochronology and tectonic syntheses at regional levels, development of new isotopic systems to constrain geochemical cycles, and continued innovation in the search for records of early life in relation to changing palaeoenvironments.
\end{abstract}

Supercontinents occupy a central position in the long term processes of the Earth system. Their amalgamations result from lateral plate-tectonic motions manifesting mantle convection, and their disaggregation, although thought by some to be externally forced by plume or hotspot activity (e.g. Storey et al. 1999), is widely considered to result from their own thermal or geometric influences upon such convection (Gurnis 1988; Anderson 1994; Lowman \& Jarvis 1999; Vaughan \& Storey 2007; O'Neill et al. 2009). Continental collisions compress land area and thus are expected to lower sea level; fragmentations involve crustal thinning and generate young seafloor, and therefore should raise sea level (Fischer 1984; Worsley et al. 1984). These eustatic effects can influence global climate by changing global albedo and rates of silicate weathering (a sink for atmospheric carbon dioxide) on exposed versus drowned continental shelves (Nance et al. 1986; Marshall et al. 1988). Chemical weathering of pyrite and organic carbon in mountain belts is a major influence on the atmospheric oxygen budget as is their burial in marine sediments. These processes are in turn dependent on global tectonics (Berner 2006). Climatic changes, plus geographic patterns of ocean circulation, will exert a profound influence on the biosphere (Valentine \& Moores 1970). Microbes play an important role in concentrating low-temperature mineral deposits through 
near-surface redox reactions (e.g. Dexter-Dyer et al. 1984; Labrenz et al. 2000) and many mineral deposits are associated with specific tectonic environments related to broader supercontinent cycles (Barley \& Groves 1992; Groves et al. 2005).

The connections illustrated above are based on concepts or a few well-constrained examples. The actual record of supercontinents on Earth is not yet well enough known to verify or modify the models in deep time. Prior to Pangaea (approximately $0.25-0.15 \mathrm{Ga})$ and Gondwana-Land $(0.52-0.18 \mathrm{Ga})$, the possible configurations and even existence of Neoproterozoic Rodinia ( $c$. $1.0-0.8 \mathrm{Ga}$ ) are intensely debated (Meert \& Torsvik 2003; Li et al. 2008; Evans 2009). Prior to Rodinia, an earlier supercontinental assemblage at $1.9-1.8 \mathrm{Ga}$ has been suggested. Although only preliminary and palaeomagnetically untested models of this supercontinent have been published (Rogers \& Santosh 2002; Zhao et al. 2002, 2004), its assembly appears to have followed tectonic processes that are remarkably similar to those of the present day (Hoffman 1988, 1989). This supercontinent is referred to by various names (e.g. Columbia, Nuna, Capricornia) but here, and below, we refer to it as Nuna (Hoffman 1997).

It is unclear whether Nuna's predecessor was a large supercontinent, or whether it was one of several large, but distinct coeval landmasses (Aspler \& Chiarenzelli 1998; Bleeker 2003). Nonetheless, numerous large igneous provinces, with ages between 2.45 and $2.2 \mathrm{Ga}$, perforate the world's 35 or so Archaean cratons and could represent an episode of globally widespread continental rifting at that time (Heaman 1997; Buchan et al. 1998; Ernst \& Buchan 2001).

Given that the Palaeoproterozoic era is defined chronometrically at 2.5-1.6 Ga (Plumb 1991), it thus encompasses one or more episodes, perhaps cycles, of global tectonics. As enumerated by the following examples, these tectonic events coincide with fundamental changes to the Earth as an integrated system of core, mantle, lithosphere, hydrosphere, atmosphere, and biosphere. Understanding these changes requires the integration of seemingly disparate geoscience disciplines. One pioneering review of this sort (Nance et al. 1986) has been followed by an incredible wealth of precise geochronological data constraining ages within the Palaeoproterozoic geological record. In this chapter we have compiled the currently available data from core to atmosphere, from late Archaean to late Mesoproterozoic time $(3.0-1.2 \mathrm{Ga})$, to provide an overview of Earth-system evolution and an up-to-date temporal and spatial framework for hypotheses concerning the global transition through Earth's 'middle ages'.

\section{Evolution of the core}

Today, the metallic core of the Earth consists of a solid inner part, with radius of about $1200 \mathrm{~km}$, surrounded by a liquid outer part with outer radius of about $3500 \mathrm{~km}$. As such, it occupies about one-sixth of the Earth's volume, and dominates the planetary concentration of the siderophile elements $\mathrm{Fe}$ and $\mathrm{Ni}$. It is generally accepted that the core was originally entirely fluid, and that through time the solid inner core nucleated and grew as the Earth cooled gradually (Jacobs 1953; Stevenson 1981; Jeanloz 1990). However, the rate of this inner-core growth is highly uncertain and depends upon various estimates of radioactive element (mainly $\mathrm{K}$ ) concentrations in the core versus mantle and crust (Nimmo et al. 2004; Davies 2007).

Recent estimates of the age of inner core nucleation, on a theoretical basis constrained by the geochemical data, are typically about $1 \mathrm{Ga}$ (Labrosse et al. 2001; Nimmo et al. 2004; Butler et al. 2005; Gubbins et al. 2008). Much discussion on this topic is confounded with discussions of the intensity of Earth's ancient geomagnetic field. This is because two of the primary energy drivers of the geodynamo are thought to be thermal and compositional convection in the outer core due to inner core crystallization (Stevenson et al. 1983). Early attempts to determine the palaeointensity of Earth's magnetic field, which is among the most laborious and controversial measurements in geophysics, suggested an abrupt increase in moment near the Archaean-Proterozoic boundary (Hale 1987). Subsequent refinements to techniques in palaeointensity (e.g. the single-crystal technique applied by Smirnov et al. 2003) have generated mixed results, but several of the measurements indicate a strong field in the earliest Proterozoic (Fig. 1a). More traditional palaeointensity techniques complete the later Proterozoic time interval with results of generally low palaeointensity (Macouin et al. 2003). There is currently no systematic test among the various palaeointensity techniques, so absolute Precambrian palaeointensity values remain ambiguous. In addition, the large apparent increase in palaeointensity at $c .1 .2 \mathrm{Ga}$ (Fig. 1a) is underpinned by sparse data that lack some standard reliability checks (Macouin et al. 2004). However, we tentatively explore the possibility that all the available records provide reliable estimates of ancient geomagnetic field strength.

Given that there is growing consensus that the inner core began to crystallize relatively late in Earth history, we speculate that the increase in palaeointensity at $1.2-1.1 \mathrm{Ga}$ could be due to the inner-core growth-related energy inputs toward geodynamo generation. In that case, the ArchaeanProterozoic interval of strong intensity, if sampled 


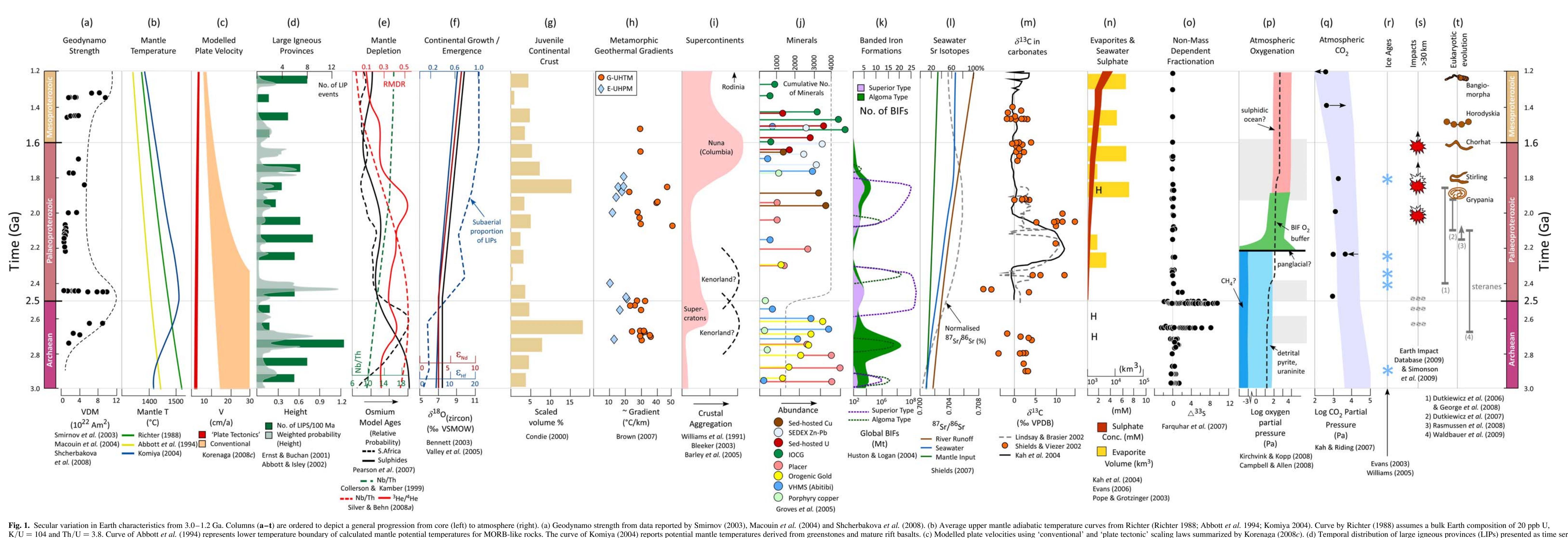

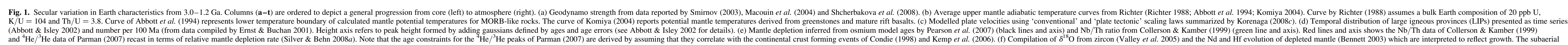

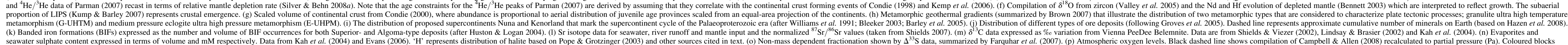


adequately, could be due to an anomalous episode of geodynamo-driving energy from the top of the core: perhaps, for example, a result of enhanced thermal gradients following a global peak in Neoarchaean subduction (Condie 1998). A more complete dataset of Archaean-Palaeoproterozoic palaeointensity measurements, with better indications of reliability for the obtained values, will be necessary to further our understanding of such ancient core processes.

\section{Mantle evolution}

The early Earth was undoubtedly hotter than at present, due to the relative abundance of radioactive isotopes that have since decayed, and the secular cooling of primordial heat from planetary accretion. Because it forms $c .80 \%$ of Earth's volume, the nature of secular cooling of the Earth's mantle carries fundamental implications for core formation, core cooling and the development of the geodynamo, the development of a modern style of plate tectonics and crustal evolution. Critical to the evolution of the mantle are the total concentrations of radioactive elements in the Earth, their spatial and temporal distribution and residence times in the core, mantle, and crust, and the degree to which layered versus whole-mantle convection can redistribute them. The precise quantification of the mantle's secular cooling is therefore intimately linked to its structure and geochemistry. These remain a subject of significant debate and have been arguably 'the most controversial subject in solid Earth sciences for the last few decades' (Korenaga 2008c). Without doubt, mantle convection is a requirement of a secularly cooling Earth (see Jaupart et al. 2007; Ogawa 2008 for recent reviews) but establishing the nature of modern convection in the modern Earth has proved difficult and is more so in its extrapolation to the geological past (Schubert et al. 2001).

Numerical modelling is one approach that has received considerable attention in attempting to constrain Earth cooling models. Such modelling commonly utilizes the simple relationship between radiogenic heat production, secular cooling and surface heat flux. Critical to these models is the way in which surface heat flux is calculated and how this heat flow is scaled to mantle convection over time. 'Conventional' models commonly calculate surface heat flux using scaling laws that assume a strong temperature dependency on viscosity such that hotter mantle convects more vigorously, thereby increasing surface heat flux. As clearly enunciated by Korenaga (2006), applying conventional heat flux scaling from current conditions back through geological time predict unrealistically hot mantle temperatures before $1 \mathrm{Ga}$ and lead to the so called 'thermal catastrophe' (Davies 1980). Several numerical models have therefore addressed different ways of modifying the scaling laws to avoid these unrealistic mantle temperatures. One way of doing this is by assuming a much higher convective Urey ratio (i.e. the measure of internal heat production to mantle heat flux) in the geological past (e.g. Schubert et al. 1980; Geoffrey 1993) than modern day estimates (Korenaga 2008c). Although this assumption overcomes problems of the thermal catastrophe in the Mesoproterozoic, the solution leads to high Archaean mantle temperatures that appear inconsistent with empirical petrological data for mantle temperatures (Abbott et al. 1994; Grove \& Parman 2004; Komiya 2004; Berry et al. 2008) (Fig. 1b).

An alternative way of alleviating the problem of a Mesoproterozoic 'thermal catastrophe' is to assume layered mantle convection rather than whole-mantle convection (e.g. Richter 1985). A layered mantle has been inferred as a means of maintaining distinct geochemical reservoirs, particularly noble gas compositions measured between midocean ridge basalts and plume-related ocean island basalts (e.g. Allegre et al. 1983; O’Nions \& Oxburgh 1983) and large-ion lithophile elements budgets of the crust and mantle (e.g. Jacobsen \& Wasserburg 1979; O'Nions et al. 1979). The nature of this layering differs between different models (c.f. Allegre et al. 1983; Kellogg et al. 1999; Gonnermann et al. 2002). However, critical to this argument is that the modelling of layered versus whole-mantle convection and its affect on present day topography supports the latter (Davies 1988), and seismic tomographic data provide evidence of subducting slabs that penetrate the lower mantle (e.g. van der Hilst et al. 1997). These observations are difficult to reconcile with the classic model of layered convection (see van Keken et al. 2002 for review).

With increasing geochemical data from a range of different sources, geochemical constraints on mantle evolution are becoming more refined, and the two-layer mantle reservoir models have necessarily become more complex (see reviews of Graham 2002; Porcelli \& Ballentine 2002; Hilton \& Porcelli 2003; Hofmann 2003; Harrison \& Ballentine 2005). These data have led to the formulation of models in which some of the chemical heterogeneity is stored in the core or deep mantle (Porcelli \& Elliott 2008), or is associated with a unmixed lower mantle 'magma ocean' (Labrosse et al. 2007), or is associated with lateral compositional variations (Trampert \& van der Hilst 2005), or is explained by filtering of incompatible trace elements associated with water release and melting associated with magnesium silicate phase changes in the mantle transition zone (Bercovici \& Karato 2003). However, a recent 
development in layered mantle geodynamics and the understanding of core-mantle interaction is the significant discovery of the post-perovskite phase transition (Murakami et al. 2004) and the realization that such a transition seems to account for many of the characteristics of the seismically recognized $\mathrm{D}^{\prime \prime}$ of the lower mantle (see Hirose \& Lay 2008 for a recent summary). The large positive Clapeyron slope of the perovskite-post-perovskite phase transition means that cold subducting slabs that reach the core-mantle boundary are likely to lead to enhanced post-perovskite formation and form lateral topography on the $\mathrm{D}^{\prime \prime}$ layer (Hernlund et al. 2005). With the addition of slab material to the $\mathrm{D}^{\prime \prime}$ layer, and its potential for enhanced melting (Hirose et al. 1999), it is likely that there will be significant geochemical implications for lower mantle enrichment and melting (see for example Kellogg et al. 1999; Labrosse et al. 2007), in addition to the potential for mantle plume generation (Hirose \& Lay 2008), both of which are yet to be resolved. The post-perovskite stability field intersects only the lowermost depths of the present mantle geotherm (Hernlund et al. 2005) and the secular cooling rate of the lowermost mantle is not well enough known to estimate the age at which this post-perovskite phase first appeared in Earth history. However, this is likely to be of importance in the secular evolution of the deep Earth.

To summarize, current geodynamical and geochemical models for the modern mantle are therefore necessarily complex and it seems that the answer may reside in a mixture of whole-mantle and episodic layered convection that is closely linked to large-scale plate tectonic processes and affects chemical heterogeneities preserved at a range of scales (Tackley 2008).

Despite the advances in understanding the geodynamics of the present-day mantle, extrapolation to the Palaeoproterozoic mantle remains elusive. In the last few years, developments in the modelling of secular cooling of the mantle have utilized surface heat flux scaled to a 'plate tectonic' model involving mantle melting at mid-ocean ridges (Korenaga 2006) or intermittent plate tectonic models in which subduction flux, indicated by geochemical proxies (e.g. the $\mathrm{Nb} / \mathrm{Th}$ ratios of Collerson \& Kamber 1999 Fig. 1e), varies over time (Silver \& Behn 2008a). These models overcome the problems of Mesoproterozoic thermal runaway, calculated back from present day conditions via conventional scaling laws, in the first case by taking account of depth-dependent mantle viscosity variations as a function of melting (Hirth \& Kohlstedt 1996) and in the second by reducing the amount of heat loss at times of plate tectonic quiescence (Silver \& Behn 2008a). Importantly, such models predict significantly reduced plate velocities during the Neoarchaean and Palaeoproterozoic eras than conventional models do (Fig. 1c) because of either the increased difficulty of subducting thicker dehydrated lithosphere (Korenaga $2008 b$ ) or the episodic nature of the supercontinent cycle (Silver \& Behn 2008a). However, they remain controversial (Korenaga 2008a; Silver \& Behn 2008b), particularly in light of recent evidence for a temperature control on lower crustal thermal conductivity (Whittington et al. 2009) and empirical estimates of Archaean mantle temperatures (Berry et al. 2008) that are higher than the model predictions (Fig. 1b). Even so, the development of models that are intimately linked to plate tectonic processes and that involve the formation and subduction of strong, plate-like lithosphere that controls mantle convection (e.g. Tackley 2000; Bercovici 2003), provide predictions from the core to the atmosphere that can be empirically constrained by the extant geological record, for example secular variations in crust and mantle geochemistry (Fig. 1d), the amalgamation and dispersal of supercontinents (Fig. 1i) and chemistry of the oceans and atmosphere (Fig. 1k, q).

Another feature of mantle evolution that has received considerable scientific attention is the formation and secular development of mantle plumes (e.g. Ernst \& Buchan 2003 and references therein). One of the expressions of the impingement of mantle plumes on Earth's lithosphere is the development of large igneous provinces (LIPS) (Ernst \& Buchan 2001, 2003) manifest as continental or oceanic flood basalts and oceanic plateaus. The geological record of LIPS (summarized by Ernst \& Buchan 2001; Abbott \& Isley 2002) recognizes a general decrease of size in younger LIP events, and an episodic distribution in time (Fig. 1d). Timeseries analysis of LIPS recognizes a c. 330 Ma cycle in the period from 3.0-1.0 Ga upon which weaker, shorter duration cycles are superimposed (Prokoph et al. 2004). As pointed out by Prokoph et al. (2004), no simple correlation exists between the identified LIP cycles and possible forcing functions, though current global initiatives to date mafic volcanism precisely (e.g. Bleeker \& Ernst 2006) should improve the likelihood of establishing such correlations. Currently, the correlations reported in Figure 1 show that LIP activity at $c \cdot 2.7-2.8 \mathrm{Ga}$ coincides with global banded iron formation (BIF) and orogenic gold formation, while a second event at $2.45 \mathrm{Ga}$ corresponds with a the major formation of Superior-type BIF. In addition, the major $2.7 \mathrm{Ga}$ peak in LIP activity lies temporally close to the peak in juvenile crust formation (Fig. 1g), a correlation that has led to the suggestion that these features may be geodynamically related (Condie 2004) and which may explain observed gold enrichment (Brimhall 1987; Pirajno 2004). 


\section{Crustal growth and emergence}

Continental crust represents only a small proportion of Earth's volume, yet it contains significant proportions of Earth's incompatible elements recorded in long-lived igneous, sedimentary and metamorphic rocks (e.g. Turekian \& Wedepohl 1961; Taylor 1964). Establishing the secular evolution of compositional changes in continental rocks therefore provides fundamental constraints on the growth of the continental crust, the evolution of the mantle from which it was extracted, and the chemical evolution of the oceans and atmosphere. However, establishing the composition of continental crust and how this changes over time is not straightforward (e.g. McLennan 1989) and has been debated intensely (see reviews of Hawkesworth \& Kemp 2006a; Rollinson 2006 for recent summaries).

One widely used approach has been the analysis of fine-grained sedimentary rocks, thought to provide a statistical representation of the upper crust, to establish the increase in volume of the continental crust over time (e.g. Allegre \& Rousseau 1984; Taylor \& McLennan 1985, 1995). Other approaches include the direct analysis of zircon age populations from juvenile continental crust (Condie 1998), or indirect analysis by assessing the chemical evolution of the depleted upper mantle from which continental crust is believed to be ultimately sourced (e.g. Bennett 2003 and references therein) (Fig. 1f). More recent developments include the integration of in situ stable and radiogenic isotope analysis (Valley et al. 2005; Hawkesworth \& Kemp 2006b).

Despite the difficulties in constraining the composition of continental crust (Rudnick et al. 2003) and the likely requirement of two-stage differentiation (e.g. Arndt \& Goldstein 1989; Rudnick 1995; Kemp et al. 2007), several fundamentally different growth models dominate the literature (for recent summary see Rino et al. 2004): rapid differentiation of the crust early in Earth's history and subsequent recycling such that there has been little subsequent increase in volume over time (e.g. Armstrong 1981, 1991); growth mainly in the Proterozoic (Hurley \& Rand 1969; Veizer \& Jansen 1979); high growth rates in the Archaean followed by slower growth in the Proterozoic (Dewey \& Windley 1981; Reymer \& Schubert 1984; Taylor \& McLennan 1995) and growth accommodated by discrete episodes of juvenile crust formation (McCulloch \& Bennett 1994; Condie 1998, 2000).

The first of these models (Armstrong 1981, 1991) seems unlikely in the light of relatively constant $\delta^{18} \mathrm{O}$ from Archaean rocks that show little evidence of extensive crustal recycling prior to $2.5 \mathrm{Ga}$ (Valley et al. 2005). These data also point towards significant crustal growth in the Archaean and so are also inconsistent with the models of dominantly Proterozoic growth (Hurley \& Rand 1969; Veizer \& Jansen 1979). In the case of progressive or episodic crustal growth, mantle depletion events should also mimic continental growth. Despite possible complexities associated with crustal recycling and questions regarding the nature of mantle convection, $\mathrm{Re}-\mathrm{Os}$ data from peridotites and platinum group alloys indicate mantle depletion events that cluster at 1.2, 1.9 and $2.7 \mathrm{Ga}$ (Pearson et al. 2007) (Fig. 1e). A temporally similar peak at $2.7-2.5 \mathrm{Ga}$ is recorded in $\mathrm{Nb} / \mathrm{Th}$ data (Collerson \& Kamber 1999) following polynomial fitting of the data (Silver \& Behn $2008 a$ ) and in the ${ }^{4} \mathrm{He} /{ }^{3} \mathrm{He}$ ocean island basalt data inferred at $2.7 \mathrm{Ga}$ and $1.9 \mathrm{Ga}$ (Parman 2007) (Fig. 1e). Although the age constraints on the mantle depletion events recorded by the $\mathrm{He}$ data are poor, the pattern of $\mathrm{Os}$ and $\mathrm{Nb} / \mathrm{Th}$ data are similar to that documented by the temporal distribution of juvenile continental crust (Fig. 1g) and considered to reflect the formation of supercontinents (Fig. 1i) (Condie 1998; Campbell \& Allen 2008), possibly linked to large-scale mantle overturn events (Condie 2000; Rino et al. 2004), and the cessation of, or decrease in, subduction flux (Silver \& Behn 2008a). Recent models integrating chemical differentiation with mantle convection also predict the episodicity of juvenile crust formation (Walzer \& Hendel 2008), as do large-scale mantle overturn events that are thought to take place on a timescale of several hundred million years (Davies 1995).

Despite the above correlations, the pattern of juvenile crust ages has been argued to be a consequence of the preservation potential within the supercontinent cycle, in particular the ability to preserve material inboard of arcs (Hawkesworth et al. 2009). Although this seems a reasonable interpretation based on the crustal record, the temporal link between mantle depletion events (Collerson \& Kamber 1999; Parman 2007; Pearson et al. 2007) and juvenile crust (Condie 1998; Campbell \& Allen 2008) is less easy to explain by preservational biases and remains a compelling observation for linking these processes. Our current preference is therefore for continental growth models that involve continental crust formation in the Archaean with subsequent reworking, recycling and the addition of juvenile material via episodic processes through the Proterozoic.

The growth of continental crust, its evolving volume and its thickness are intimately related to the evolution of the mantle (e.g. Hynes 2001). These characteristics also play a critical role in continental freeboard, the mean elevation of continental crust above sea level, and the emergence of the continents (e.g. Wise 1974; Eriksson et al. 2006). The emergence of the continental crust above sea 
level in turn influences the nature of sedimentation (Eriksson et al. 2005b) and enables weathering that affects ocean and atmospheric compositions. Several lines of evidence point to continental emergence around the Archaean-Proterozoic boundary, primarily in the form of distinctive geochemical trends that require low-temperature alteration and crustal recycling. One such line of evidence comes from a recent compilation of $\delta^{18} \mathrm{O}$ data from the zircons of juvenile rocks, which show a clear trend of relatively constant Archaean values with increasing values at $c .2 .5 \mathrm{Ga}$ (Valley et al. 2005) (Fig. 1f). This trend mimics those recorded in $\mathrm{Hf}$ and $\mathrm{Nd}$ isotopic data from juvenile granitic rocks (Fig. 1f), which is thought to represent depletion of the mantle associated with extraction of the continental crust (Bennett 2003). The pattern of oxygen isotopic variation in zircon is explained by complex contributions of various processes (Valley et al. 2005). However, a requirement is for a component of lowtemperature fractionation commonly interpreted to be associated with continental weathering, the recycling of supracrustal rocks and subsequent melting.

The most recent data to place temporal constraints on continental emergence comes from an analysis of submarine versus subaerial LIP (Kump \& Barley 2007) (Fig 1f), which shows an abrupt increase in the secular variation of subaerial LIPs at $c .2 .5 \mathrm{Ga}$. This is thought to have had significant global repercussions with respect to the increase in atmospheric oxygen levels (Kump \& Barley 2007) and is discussed further below. Recent modelling of continental emergence that links continental freeboard with different models for cooling of the Earth indicates that the emergent continental crust was only 2-3\% of the Earth's surface area during the Archaean, a stark contrast to present day values of c. 27\% (Flament et al. 2008).

Sedimentary rocks document the physical, chemical, and biological interface between the Earth's crust and its changing Precambrian surface environments (see Eriksson et al. 2005 b for an overview). Palaeoproterozoic sedimentary basins share many of the same features as their modern counterparts, whether in rift settings (Sengor \& Natal'in 2001), passive margins (Bradley 2008), strike-slip basins (e.g. Ritts \& Grotzinger 1994), or foreland basins (e.g. Grotzinger et al. 1988). Ironically, Precambrian sedimentary structures can be much easier to decipher than their Phanerozoic counterparts due to the lack of bioturbation in pre-metazoan depositional environments. However, there are some notable differences between Precambrian and modern clastic sedimentation systems. Most notably, sandstones of pre-Devonian river systems are commonly characterized by sheet-braided geometry with greater channel widths ascribed to the lack of vegetative slope stabilization (e.g. Long
2006). The deposits of specific palaeoenvironments such as aeolianites have a temporal distribution modulated by long-term preservational potential and possible relationships to phases of supercontinental cyclicity (Eriksson \& Simpson 1998), as is also the case for glaciogenic deposits, which are summarized below. Also discussed below are factors determining the temporal variation in redoxsensitive mineral clasts such as detrital pyrite and uraninite (Fig. 1p), and the abundances and chemical compositions of banded iron-formations (Fig. 1k), evaporites (Fig. 1n), and carbonate chemistry and structure (Grotzinger 1989; Grotzinger \& James 2000).

\section{Supercontinents}

All supercontinents older than Pangaea are conjectural in both existence and palaeogeography. The concept of Precambrian episodicity, and hence supercontinental cycles, arises from global peaks in isotopic age determinations, in which the basic result has not changed throughout a half-century of compilation (Gastil 1960; Worsley et al. 1984; Nance et al. 1986, 1988; Condie 1995, 1998, 2000; Campbell \& Allen 2008). The most prominent age peaks are at 2.7-2.6 and $1.9-1.8 \mathrm{Ga}$, with some studies also indicating a peak at $1.2-1.1 \mathrm{Ga}$. The age peaks are global in distribution, although many regions contain regional signatures, and they are best correlated to collisional accretion of cratons in North America (Hoffman 1988, 1989). This led to the naming of successively older pre-Pangaean supercontinents Grenvilleland, Hudsonland and Kenorland (Williams et al. 1991). The younger two of these entities are most commonly given alternative names Rodinia (for recent reviews, see Li et al. 2008; Evans 2009), and Nuna or Columbia (Hoffman 1997; Rogers \& Santosh 2002); 'Grenvilleland' has been forgotten, and 'Hudsonland' almost so (cf. Pesonen et al. 2003). Here we favour 'Nuna' for the supercontinent that assembled at 1.9-1.8 Ga (see Zhao et al. 2002 for a global review) because it represents a preferred renaming of 'Hudsonland' by one of the co-authors of the original study (Hoffman 1997) and has priority over 'Columbia' (Rogers \& Santosh 2002), the latter of which was also defined by a specified palaeogeography that has been modified in subsequent references (e.g. Meert 2002; Zhao et al. 2002, 2004).

There are additional names for putative Palaeoproterozoic continental assemblages. Capricornia (Krapez 1999) refers to a model for the early amalgamation of Australia and hypothesized adjacent cratons Laurentia, India, Antarctica, and Kalahari. Arctica is defined as the postulated assemblage of Siberia with northern Laurentia, and Atlantica 
comprises the proposed long-lived amalgamation of West (and parts of northern) Africa, Amazon, São Francisco-Congo, and Rio de la Plata (Rogers 1996). Of these, a Siberia-northern Laurentia connection, if not directly adjacent then slightly separated, is allowed by numerous independent palaeomagnetic comparisons from 1.5 to $1.0 \mathrm{Ga}$ (Pisarevsky \& Natapov 2003; Pisarevsky et al. 2008; Wingate et al. 2009), and lack of tectonic activity after $1860 \mathrm{Ma}$ in southern Siberia would suggest that this position had been established by that time (Poller et al. 2005; Pisarevsky et al. 2008). A long-lived Atlantica continent is difficult to test palaeomagnetically, due to a dearth of reliable results from its constituent cratons (Meert 2002; Pesonen et al. 2003). Minor transcurrent motions between West Africa and Amazon, sometime between original craton assembly at $2.1 \mathrm{Ga}$ (Ledru et al. 1994) and their Gondwanan amalgamation in the Cambrian (e.g. Trindade et al. 2006), are proposed based on limited palaeomagnetic data from those two blocks (Onstott \& Hargraves 1981; Onstott et al. 1984; Nomade et al. 2003). Such minor amounts of relative displacement would preserve the proposed tectonic correlations among the Atlantica cratons, but further palaeomagnetic testing is needed.

Nuna, commonly under the guise of 'Columbia', is commonly reconstructed with many cratonic juxtapositions taken from inferred models of Rodinia (Rogers \& Santosh 2002; Zhao et al. 2002, 2004; Hou et al. 2008a, b). These models lack robust palaeomagnetic constraints, and the reconstructions are commonly distorted by unscaled cut-outs from a Mercator projection of Pangaea. When palaeomagnetic data are incorporated into geometrically accurate reconstructions, the sparsity of reliable results has led authors to conflicting conclusions of either non-existence of a $1.8 \mathrm{Ga}$ supercontinent altogether (Meert 2002), or one that accommodated substantial internal shears (Laurentia-Baltica motions illustrated in Pesonen et al. 2003), or the consideration of at most a few fragments with applicable data from discrete time intervals (Li 2000; Salminen \& Pesonen 2007; Bispo-Santos et al. 2008).

The most robust long-lived juxtaposition of Palaeo-Mesoproterozoic cratons is that of Laurentia and Baltica throughout the interval 1.8-1.1 Ga. First proposed on geological grounds and named 'NENA' (northern Europe-North America, Gower et al. 1990), this juxtaposition finds palaeomagnetic support from numerous results throughout that interval, defining a common apparent polar wander path when poles are rotated according to the reconstruction (Evans \& Pisarevsky 2008; Salminen et al.). The NENA reconstruction is distinct in detail from the commonly depicted juxtaposition of Hoffman (1988) that has been reproduced in Zhao et al.
(2002, 2004), which is not supported palaeomagnetically. NENA is a specific reconstruction between two cratons and is distinct from Nuna, the supercontinent proposed to have assembled at $1.9-1.8 \mathrm{Ga}$ without particular palaeogeographic specifications. By coincidence, the two names are similar, and NENA appears to be a robustly constrained component of Nuna. Payne et al. extend the Palaeo-Mesoproterozoic apparent polar wander comparisons to include Siberia, North and West Australia, and the Mawson Continent (Gawler craton with original extensions into Antarctica). The Australian proto-continent is restored in that analysis by the same sense of relative rotations as proposed by Betts \& Giles (2006). As more data from other cratons accumulate through the $1.8-1.5 \mathrm{Ga}$ interval, this approach should lead to a successful first-order solution of Nuna's palaeogeography.

Kenorland is the name given to the palaeogeographically unspecified supercontinent that might have formed in the Neoarchaean era (Williams et al. 1991). Its etymology derives from the Kenoran orogeny (Stockwell 1982) that represents cratonization of the Superior craton at about 2.72$2.68 \mathrm{Ga}$ (Card \& Poulsen 1998; Percival et al. 2006) and of that age or younger in the Neoarchaean on other cratons (Bleeker 2003). Breakup of Kenorland would be represented by numerous large igneous provinces starting with a global pulse at $2.45 \mathrm{Ga}$ (Heaman 1997). Subsequently, the meaning of 'Kenorland' has varied. Aspler \& Chiaranzelli (1998) referred to Kenorland as the specified palaeogeography of ancestral North America, with an interpretation of the TransHudson and related orogens that accommodated at most accordion-like oceanic opening and reclosing, but not extensive reshuffling of cratons. Baltica and Siberia were included in unspecified palaeogeographic configurations. A second proposed supercontinent ('Zimvaalbara' comprising Zimbabwe, Kaapvaal, Pilbara and perhaps São Francisco and cratons in India) is proposed to have assembled and begun to break up somewhat earlier than Kenorland, at 2.9 and $2.65 \mathrm{Ga}$, respectively; yet its final fragmentation was conjectured at $2.45-2.1 \mathrm{Ga}$, simultaneous with that of Kenorland (Aspler \& Chiarenzelli 1998).

Bleeker (2003) chose a different nomenclature that referred to 'Kenorland' as a possible solution to Neoarchaean-Palaeoproterozoic palaeogeography whereby all (or most) cratons were joined together; he also proposed an alternative solution of palaeogeographically independent 'supercratons' that would each include a cluster of presently preserved cratons. Three supercratons were exemplified and distinguished by age of cratonization: Vaalbara $(2.9 \mathrm{Ga})$, Superia $(2.7 \mathrm{Ga})$, and Sclavia 
$(2.6 \mathrm{Ga})$. Vaalbara has the longest history of recognition and palaeomagnetic testing (Cheney 1996; Wingate 1998; Zegers et al. 1998) with the most recent tests allowing a direct juxtaposition (Strik et al. 2003; de Kock et al. 2009). Superia has become more completely specified by the geometric constraints of precisely dated, intersecting dyke swarms across Superior, Kola-Karelia, Hearne, and Wyoming cratons through the interval 2.52.1 Ga (Bleeker \& Ernst 2006). Aside from Slave craton, the additional elements of Sclavia remain unknown. Lastly, a completely different view of Kenorland (Barley et al. 2005) entails inclusion of all (or most) of the world's cratons, following assembly as late as $2.45 \mathrm{Ga}$, and breakup at $2.25-$ $2.1 \mathrm{Ga}$. This definition would be consistent with a global nadir in isotopic ages during the 2.45$2.25 \mathrm{Ga}$ interval, proposed earlier as a time of supercontinent assembly (Condie 1995), or a more recently and radically, a cessation of plate tectonics altogether (Condie et al. 2009).

Palaeogeographic constraints on these proposed Neoarchaean-Palaeoproterozoic supercontinents and supercratons, other than the aforementioned Vaalbara, are limited by a small number of reliable palaeomagnetic data (Evans \& Pisarevsky 2008). The best progress has been made in the Superior craton, where a series of precise $\mathrm{U}-\mathrm{Pb}$ ages on mafic dyke swarms has been closely integrated with palaeomagnetic studies at the same localities, and with particular attention to baked-contact tests to demonstrate primary ages of magnetic remanence (e.g. Buchan et al. 2007; Halls et al. 2008). If a similar strategy is applied to other cratons then the solution of Kenorland or supercraton configurations will be much closer to realization.

Finally, Piper (2003) incorporated the extant Archaean-Palaeoproterozoic cratons into a longlived supercontinent (duration 2.9-2.2 Ga) named 'Protopangaea'. This assemblage mirrors Piper's proposed Meso-Neoproterozoic supercontinent 'Palaeopangaea' (Piper 2007). Both are based on broad-brush compilations of the entire database containing a complex mixture of primary and secondary magnetizations rather than on precise palaeomagnetic comparisons of the most reliable data. Meert \& Torsvik (2004) point out some of the problems with this approach, and $\mathrm{Li}$ et al. (2009) demonstrate specific quantitative refutations of the reconstructions.

Linked to the supercontinent debate is the controversy regarding the timing of initiation of a modern-style of plate tectonics (cf. Stern 2005; Cawood et al. 2006). A range of geological, geodynamic and geochemical constraints (recently summarized by Condie \& Kroner 2008; Shirey et al. 2008; van Hunen et al. 2008), suggest the strong likelihood of plate tectonic behaviour in the Palaeoproterozoic and possibly back into the Archaean; an inference also made by Brown (2007) based on the presence of characteristic high pressure-lower temperature and high temperature-lower pressure metamorphic mineral assemblages associated with subduction and arcs respectively (Fig. 1h). Recent numerical models are consistent with this interpretation (e.g. Labrosse $\&$ Jaupart 2007). For a recent summary of the different aspects of the ongoing debate the reader is referred to Condie \& Pease (2008) and references therein.

In summary, although Rodinia's configuration remains highly uncertain, a working model of its predecessor Nuna is being assembled rapidly with the acquisition of new geochronological and palaeomagnetic data considered in the context of global tectonic constraints. It remains uncertain whether there was a supercontinent at all during the Archaean-Proterozoic transition, and if so, when it existed and how its internal configuration of cratons was arranged. Figure 1i depicts these uncertainties using the template illustration of Bleeker (2003). Creation of a global stratigraphic database (Eglington et al. 2009) not only illustrates the growing wealth of global age constraints on the Palaeoproterozoic rock record, but also shows which stratigraphic units are in greatest need of dating, and which units are most promising for successful preservation of primary palaeomagnetic remanence directions that will allow further progress in supercontinent reconstruction.

\section{Minerals and mineral deposits}

Understanding the secular development of mineral abundances and concentrations has importance for the exploration and exploitation of economic ore deposits. A recent review of the evolution of Earth's minerals (Hazen et al. 2008) recognizes 10 stages of increasing mineral diversity associated with major global changes. In the timeline of interest here, the largest increase in mineral types has been linked to the development of the oxygenated atmosphere (Hazen et al. 2008). This event, the timing of which is best displayed by changes in the non-mass-dependent fractionation of sulphur isotopes (see below), entailed a significant increase in the number of mineral species (Fig. 1j) and correlates with the timing of the major deposits of Superior-type BIFs (Fig. 1k) and systematic changes in mineral deposits through time (Fig. 1j) (Barley \& Groves 1992; Groves et al. 2005). The main peaks of BIF formation and deposition of unconformity-related, sedimenthosted uranium deposits at $<1800 \mathrm{Ma}$ are likely to represent the changing environmental conditions 
(see below). In contrast, the spike of orogenic gold deposits at $c .2 .7 \mathrm{Ga}$ and volcanic-hosted massive sulphide deposits at $c .2 .6 \mathrm{Ga}$ and $c .1 .7 \mathrm{Ga}$, which temporally correspond to peaks in juvenile continental crust production (Fig. 1g) and mantle depletion events (Fig. 1e) may represent fundamental differences in the nature of tectonic processes around the Archaean-Proterozoic boundary (Groves et al. 2005). These are speculated to be associated with the development of Earth's first supercontinent (Barley \& Groves 1992) and an increased preservation potential due to thicker subcontinental mantle lithosphere in the geological past (Groves et al. 2005).

\section{The evolving ocean and atmosphere}

Proxies for the secular evolution of the Neoarchaean-Proterozoic surface palaeoenvironment are numerous (Fig. 1k-q), commonly contentious, and often deeply interrelated in the development of conceptual models. Nevertheless, profound change is apparent, reflecting a combination of secular and cyclic trends. Here the development of this paper will deviate from its template of discussing the Earth system from its interior to its exterior, because one proxy in particular, the non-mass-dependent sulphur isotope system, is robust enough to provide a conceptual and temporal context for all the others.

Anomalous variation among the four stable sulphur isotope ratios, deviating from purely massdependent effects, are common in Archaean and earliest Proterozoic sedimentary pyrites (Farquhar et al. 2000). The deviations are thought to arise from gas-phase sulphur reactions in the upper atmosphere with concomitant mixing into seawater, with further constraints on sulphur speciation provided by increasingly refined datasets (e.g. Ono et al. 2003, 2009a, b). The termination of this non-mass-dependent fractionation signal is now estimated at $c$. 2.4-2.32 Ga (Bekker et al. 2004). Atmospheric modelling suggests that it was caused by either the rise of $\mathrm{O}_{2}$ above $10^{-5}$ of present atmospheric levels (Pavlov \& Kasting 2002) or loss of $\mathrm{CH}_{4}$ below a critical threshold of $c .10 \mathrm{ppmv}$ due to a shrinking ecological role of methanogenic producers (Zahnle et al. 2006). The collapse of methane from formerly high levels in the Archaean atmosphere (reviewed by Kasting 2005) probably plays a large role, not only the oxygenation history, but also the occurrence of Palaeoproterozoic ice ages, which will be discussed below. The combined data point to the 2.4-2.3 Ga interval as host to a 'Great Oxidation Event' (GOE: Cloud 1968; Holland 2002) during which Earth's surface environment changed profoundly and irreversibly.
Possible changes in atmospheric oxidation state can be estimated by age variations in the non-massdependent signal (Fig. 1o). Many data now exist for the crucial interval of 3.0-2.4 Ga (Ohmoto et al. 2006; Farquhar et al. 2007; Kaufman et al. 2007; Ono et al. 2009a, $b$ ) and perhaps the most compelling evidence for a 'whiff' of oxygen prior to $2.4 \mathrm{Ga}$ is furnished by Mo and $\mathrm{Re}$ concentration peaks in black shales at $2.5 \mathrm{Ga}$ (Anbar et al. 2007; Wille et al. 2007). Much of the inferred global nature of these peaks depends on the correlation of signals between the Pilbara and Kaapvaal cratons, whereas a subsequent palaeomagnetic reconstruction of the blocks places them in direct juxtaposition (de Kock et al. 2009). More records of similar nature are needed from other cratons through this interval, to substantiate the global nature of any hypothesized oxygenation events. Localized, photosynthetically produced 'oxygen oases' could attain ppm-level $\mathrm{O}_{2}$ concentrations within plumes dissipating into the methane-rich Neoarchaean troposphere in a timescale of hours to days (Pavlov et al. 2001).

The causes of the GOE remain unclear. Traditionally attributed to development of photosystem II in cyanobacteria (Cloud 1968; Kirschvink \& Kopp 2008) or enhanced burial rates of organic carbon produced by that process (Karhu \& Holland 1996), other potential long-term sources of oxidizing agents involve dissociation of atmospheric methane coupled to $\mathrm{H}_{2}$ escape (Catling et al. 2001; Catling \& Claire 2005), or the changing oxidative state of the upper mantle coupled to hydrothermal alteration of seafloor basalts (Kasting et al. 1993; Kump et al. 2001; Holland 2002). Finally, a qualitative empirical relationship between continental collisions and global oxygen increases over the past three billion years (Campbell \& Allen 2008), linked to carbon and sulphur burial through enhanced physical weathering and sediment transport in mountain belts, is rendered particularly speculative for the GOE due to the poorly understood history of Palaeoproterozoic supercontinents or supercratons (see above). Widespread consideration of the non-biological alternatives has been motivated primarily by the apparent antiquity of molecular biomarkers for photosynthesizing organisms as old as $2.7 \mathrm{Ga}$, about $300-400$ million years prior to the GOE (Brocks et al. 1999); however, the reliability of those records is currently debated (Eigenbrode et al. 2008; Rasmussen et al. 2008; Waldbauer et al. 2009).

Returning to the ocean, banded iron formations are a prima facie example of non-uniformitarianism in the Earth's palaeoenvironment. Deposited widely prior to $1.85 \mathrm{Ga}$ (Fig. 1k), they are nearly absent in the subsequent geological record, apart from a few small occurrences or unusual associations with 
Neoproterozoic low-latitude glacial deposits of putative Snowball Earth events (Kirschvink 1992; Klein \& Beukes 1992). The marked concentration of iron formation in the Palaeoproterozoic era has traditionally been construed as an indication of atmospheric oxidation at about that time (e.g. Cloud 1968) and that element is no doubt part of the story. However, recent research on iron formations using geochemical and isotopic tracers is painting a more refined picture of oceanic evolution.

Iron formations are broadly categorized into two classes, one with close association to volcanic successions (Algoma-type), and one without (Superiortype) (Gross 1965; Gross 1983). The Algoma-type iron formations are distributed throughout the Archaean sedimentary record, whereas Superiortype deposits only become significant at $2.6 \mathrm{Ga}$ and later (Huston \& Logan 2004) (Fig. 1k). By $2.5 \mathrm{Ga}$, Superior-type iron formations predominate, to the extent that 'Siderian' was informally proposed as the first period of the Palaeoproterozoic era (Plumb 1991). With refined global geochronology, the global peak in Palaeoproterozoic iron formation (e.g. Klein 2005 and references therein) appears to split into two modes, at $c$. $2.45 \mathrm{Ga}$ and c. $1.9 \mathrm{Ga}$ (Isley \& Abbott 1999; Huston \& Logan 2004), although some large deposits remain imprecisely dated (e.g. Krivoy Rog, Ukraine; Simandou, West Africa). The temporal distribution of iron formation is closely matched by the occurrence of thick, massive seafloor calcium carbonate cements (Grotzinger \& Kasting 1993), commonly with crystalline microtextures linked to high $\mathrm{Fe}$ concentrations in seawater (Sumner \& Grotzinger 1996).

Detailed petrological and facies analysis of iron formations has led to models with varying degrees of ocean stratification (e.g. Klein 2005; Beukes \& Gutzmer 2008), but of concern to the present compilation are the broader trends in Earth's palaeoenvironmental evolution. Do the timevarying abundances of iron formations through the Archaean-Proterozoic transition represent fundamental changes in oceanography? At the older end of that age range, the answer is likely to be 'no'. Trendall (2002) discussed the requirement of tectonic stability to allow accumulation of the giant iron formations, and with the exception of the c. $1.9 \mathrm{Ga}$ deposits, many of the large iron formations appear at the first submergence of each craton following initial amalgamation. If so, the initial peak in iron formations between 2.7 and $2.4 \mathrm{Ga}$ (Fig. 1k) has causative correlation with other records such as continental emergence (Fig. 1f). The apparently abrupt end of the first pulse of iron formations at c. $2.4 \mathrm{Ga}$ remains to be tested by further geochronology (Krivoy Rog, Simandou), but its close temporal association with the rise of atmospheric oxygen strongly suggests a causal connection. Possible feedbacks involving phosphorus limitation on primary production (Bjerrum \& Canfield 2002) have been disputed on quantitative grounds (Konhauser et al. 2007). However, fractionations of $\mathrm{Fe}$ isotopes in sedimentary pyrite appear to support the close coincidence between the timing of oxygenation in the atmosphere and the ocean (Rouxel et al. 2005).

Renewal of iron-formation deposition at 2.0$1.8 \mathrm{Ga}$ could also indicate profound changes in the hydrosphere. The so-called 'Canfield ocean' model (Canfield 1998, 2005; Anbar \& Knoll 2002) is the suggestion that after atmospheric oxidation, the increased weathering of continental sulphide minerals brought reactive sulphate ions into the marine realm, where sulphate-reducing bacteria responded with enhanced pyrite formation, thus stripping seawater of its hydrothermally generated Fe. In this model, the disappearance of iron formations at $c .1 .8 \mathrm{Ga}$ reflects the change to more reducing, sulphidic conditions rather than the deep ocean turning oxic. Meanwhile, the upper layer of seawater would remain oxygenated in contact with the post-GOE atmosphere; this first-order stratification is proposed to have persisted until the end of Precambrian time (Canfield et al. 2008). Despite some criticism (e.g. Holland 2006), the model has passed initial tests using depth-dependent iron speciation and sulphur stable isotopic variations in Mesoproterozoic marine sediments (Shen et al. 2002, 2003), patterns of trace metal concentrations (Anbar \& Knoll 2002), isotopes (Arnold et al. 2004) and molecular biomarkers (Brocks et al. 2005).

Amid these novel geochemical proxies for hydrospheric and biospheric evolution, more traditionally studied isotopic systems show equally dramatic variations. One of the largest seawater carbon-isotopic anomalies in Earth history is known as the 'Lomagundi' or 'Jatuli' event respectively after the c. $2.1 \mathrm{Ga}$ strata in Zimbabwe or Karelia where it was first documented (cf. Schidlowski et al. 1975) with typical values as high as $+10 \%$ o (Fig. 1m). An elegantly simple model attributed the peak to organic-carbon burial associated with evolution of oxygenic photosynthesis and, consequently, the rise of atmospheric oxygen (Karhu \& Holland 1996). As discussed below, however, there is (contested) evidence that the advent of oxygenic photosynthesis could have preceded the isotopic peak by at least several hundred million years. Although the most enriched ${ }^{13} \mathrm{C}$ values were probably generated in restricted, evaporative basins, such enrichments may well have been mere additions to a global peak, as indicated by the global extent of the signal (Melezhik et al. 1999, 2005a, b). 
Rather than a single, long-lived LomagundiJatuli event spanning the entire interval of 2.2$2.06 \mathrm{Ga}$ (Karhu \& Holland 1996), evidence has now accumulated for multiple positive excursions with intervening non-enriched values through that period (Buick et al. 1998; Bekker et al. 2001, 2006). Recent $\mathrm{U}-\mathrm{Pb}$ dating on interstratified volcaniclastic rocks in Fennoscandia has constrained the end of the event to $c .2 .06 \mathrm{Ga}$ (Melezhik et al. 2007), but the earliest enrichments have been more difficult to date. The oldest strongly ${ }^{13} \mathrm{C}$-enriched carbonate units, in the Duitschland Formation of South Africa (Bekker et al. 2001), are older than $2316 \pm 7$ Ma based on $\mathrm{Re}-\mathrm{Os}$ of diagenetic pyrite from the stratigraphically overlying Timeball Hill shales (Bekker et al. 2004). Those same pyritic shales lack a non-mass-dependent sulphur-isotope fractionation signal (Bekker et al. 2004) and thus the onset of the Lomagundi-Jatuli event(s) coincides exactly, to the best knowledge of available ages, with atmospheric oxidation above $10^{-5}$ of present atmospheric levels. These events directly follow the only Palaeoproterozoic ice age with a ${ }^{13} \mathrm{C}$-depleted cap carbonate, which left a record on two palaeocontinents if the correlations of Bekker et al. (2006) are correct. The relationship between Palaeoproterozoic ice ages and Earth system evolution will be explored further, below.

The strontium isotopic composition of seawater, as recorded in carbonate rocks, involves more difficult analytical methods, and although well established for the Phanerozoic Eon, is relatively poorly constrained for Precambrian time (Shields \& Veizer 2002). Data from the Palaeoproterozoic and surrounding intervals are sparse, and subject to uncertainties in age as well as the minimumaltered values. Nonetheless, a noticeable pattern of increasing ${ }^{87} \mathrm{Sr} /{ }^{86} \mathrm{Sr}$, away from the inferred (slowly increasing) mantle value, characterizes the general Palaeoproterozoic trend ('seawater' curve in Fig. 11). As Shields \& Veizer (2002) noted, this probably indicates greater continental emergence and riverine runoff of radiogenic strontium through the Archaean-Palaeoproterozoic interval. Shields (2007) provided a more sophisticated model of these processes, including rough estimates of carbonate/evaporite dissolution as a contributor to the riverine runoff component, to produce a percentage estimate of the riverine contribution to seawater ${ }^{87} \mathrm{Sr} /{ }^{86} \mathrm{Sr}$ ratios through time (dashed curve in Fig. 11). Even with this more detailed model, the first-order interpretation remains valid. However, the critical period for testing the connection with continental emergence (Fig. 1f), that is 2.7$1.9 \mathrm{Ga}$, is represented by a scant number of data (Shields \& Veizer 2002).

Long-term secular evolution of oceanic chemistry can also be measured by compositional and sedimentological trends in carbonates and evaporites. Grotzinger (1989) and Grotzinger \& James (2000) noted the abundance of carbonate platforms mirroring the growth of large sedimentary basins due to stable cratonization, much like the pattern observed for iron formations. The latter study also illustrated the successive peaks in ages of: aragonite crystal fans/herringbone calcite, tidal flat tufas, molar tooth structures, giant ooids, and various biogenic features of Archaean-Proterozoic sedimentary history. Not all of these records are well understood, but as noted above, disappearance of aragonite crystal fans and herringbone calcite is best correlated to the end of iron formation deposition and thus broadly to the rise of atmospheric oxygen.

Ocean palaeochemistry can also be inferred from the record of evaporite deposits, which in the Palaeoproterozoic era consist almost entirely of pseudomorphs after the original minerals. Evans (2006) compiled volume estimates for the largest evaporite basins through Earth history, summarized here in Figure 1n. A previous compilation (Grotzinger \& Kasting 1993) described sulphate evaporites as old as $c .1 .7 \mathrm{Ga}$ and no older, but there is more recent recognition of common sulphate pseudomorphs in sedimentary successions at c. 2.2$2.1 \mathrm{Ga}$ (reviewed by Pope \& Grotzinger 2003; Evans 2006). Those gypsum- or anhydrite-bearing strata are usually associated with redbeds and ${ }^{13} \mathrm{C}$-enriched carbonates of the Lomagundi-Jatuli event (Melezhik et al. 2005b). Evaporite deposits of both younger (Pope \& Grotzinger 2003) and older age (Buick 1992; Eriksson et al. 2005a) contain an evaporative sequence from carbonate directly to halite, excluding sulphate. Temporal correlation of halite-dominated evaporites with the peaks in iron-formation (Fig. $1 \mathrm{k}, \mathrm{n}$ ) conforms to the model of Fe-oxide seawater with low sulphate content (pre-2.4 Ga, plus 2.0-1.8 Ga), alternating with Fe-sulphidic deepwater driven by mildly oxidized surface water with higher sulphate content (Anbar \& Knoll 2002). A rising oceanic sulphate reservoir through the Proterozoic Eon is also inferred by modelling rates of sulphur isotope excursions through sedimentary sections (Kah et al. 2004; Fig. 1n).

\section{The evolving palaeoclimate and biosphere}

Palaeoproterozoic climate changes were as extreme as any in Earth history, with low-latitude ice ages interrupting an otherwise dominantly ice-free record (Evans 2003). Indications of a background state of hot $\left(55-85{ }^{\circ} \mathrm{C}\right)$ Archaean oceans, from ${ }^{18} \mathrm{O}$ records of chert and phosphate (Knauth \& Lowe 2003; Knauth 2005), are controversial (cf. contrasting views of Lowe \& Tice 2007; Shields 
\& Kasting 2007; van den Boorn et al. 2007). Regardless, basal clades of both eubacteria and archaea were likely thermophilic (Boussau et al. 2008). The early fossil record of life on Earth, especially from ages older than $3.0 \mathrm{Ga}$, is fragmentary and ardently debated (e.g. Brasier et al. 2002; Rose et al. 2006; Westall 2009). Microbial activity of some sort is evident from the presence of wrinkle mat textures in sedimentary rocks as old as 2.9 and even 3.2 Ga (Noffke et al. 2003, 2006a, b, 2008). Stromatolites of the Tumbiana Formation, Western Australia, show an impressive diversity of forms (Buick 1992) that occupied a varied array of littoral marine environments (Sakurai et al. 2005); they also contain putative nano/microfossils (Lepot et al. 2008). Molecular biomarkers also support the existence of extant late Archaean prokaryotes: although Rasmussen et al. (2008) have reinterpreted the methylhopane (and sterane, see below) record from 2.7 Ga shales in Western Australia (Brocks et al. 1999) as a post-metamorphic feature, additional records from $2.7-2.5 \mathrm{Ga}$ in the same succession show facies-dependent and thus possible palaeo-ecological distributions of 2-alpha and 3-beta methylhopanes (Eigenbrode et al. 2008) that are less likely due to post-metamorphic infiltration. A similar test of varying biomarker proportions among sedimentary and volcanic facies in the Abitibi greenstone belt of southern Canada, indicates possible archaeal and bacterial activity coincident with hydrothermal gold precipitation at 2.67 Ga (Ventura et al. 2007).

The eukaryotic fossil record, prior to $1.2 \mathrm{Ga}$, is equally controversial. Examples are described here in order of increasing age. At the younger end of the interval covered by this review (Fig. 1t), the record of bangiophyte red algae, in northern Canada, presents the oldest phylogenetically pinpointed eukaryotic body fossils (Butterfield 2000) and a robust starting point for considering older examples. The taxonomic affiliations of such older 'eukaryotic' fossils is inferred from their sizes and complexities (Knoll et al. 2006), including many simple and ornamented acritarchs, and various filamentous forms. Within the macroscale, the next older putative eukaryotic fossil is Horodyskia, found in $c$. $1.5-1.1 \mathrm{Ga}$ strata in Western Australia and North America (reviewed by Fedonkin \& Yochelson 2002; Grey et al. 2002; Martin 2004). Informally known as 'strings of beads', Horodyskia is difficult to place taxonomically; Knoll et al. (2006) consider it to be 'a problematic macrofossil whose eukaryotic affinities are probable, but not beyond debate.'

The next two older macrofossils have been purported to preserve the trails of motile, multicellular organisms and are more contentious than the younger taxa outlined above. The first, in the
Chorhat sandstone of the lowermost Vindhyan basin in India (Seilacher et al. 1998) attains Palaeoproterozoic antiquity on the merits of two concurrent and independent high-precision $\mathrm{U}-\mathrm{Pb}$ studies (Rasmussen et al. 2002b; Ray et al. 2002). However, Seilacher (2007) has subsequently introduced a viable alternative hypothesis that the Chorhat traces could represent (biogenic?) gas structures trapped beneath a microbial mat. The second, consisting of discoidal and furrowed impressions in sandstone of the Stirling Ranges in Western Australia (Cruse \& Harris 1994; Rasmussen et al. 2002a) has recently been dated to the interval 1960-1800 Ma (Rasmussen et al. 2004). An extensive discussion on these putative trace fossils retains the original interpretation of their being produced by 'motile, mucus-producing, probably multicellular organisms', which on the basis of size alone were probably eukaryotic (Bengtson et al. 2007). However, recent discovery of furrowed trails produced by extant Gromia amoebas may provide an adequate explanation for the Stirling biota (Matz et al. 2008); such an explanation needs further testing.

The oldest likely eukaryotic body fossil, Grypania spiralis, is found in the $c .1 .88 \mathrm{Ga}$ Negaunee iron-formation (Han \& Runnegar 1992; Schneider et al. 2002), coeval with the spectacular palaeontological record of the nearby Gunflint Chert (Tyler \& Barghoorn 1954; Fralick et al. 2002) and only slightly younger than the equally impressive Belcher Islands microflora (Hofmann 1976) at c. 2.0 Ga (Chandler \& Parrish 1989). Classification of Grypania is based on its morphological similarity to Mesoproterozoic occurrences from North China and North America (Walter et al. 1990). A recent report describing a spinose acritarch in amphibolite-grade Archaean metasedimentary rocks of South Australia (Zang 2007) seems less convincing.

Apart from body fossils, evidence for eukaryotic life in the Palaeoproterozoic also includes the molecular biomarker record of steranes. Sterol biosynthesis is largely, although not entirely, limited to the eukaryotic realm (see discussion in Kirschvink \& Kopp 2008; Waldbauer et al. 2009). Sensationally old steranes were identified in the $2.7 \mathrm{Ga}$ Jeerinah Formation of Western Australia (Brocks et al. 1999, 2003a, b). However, Rasmussen et al. (2008) attributed these signals to a secondary fluid migration into the boreholes, at some unknown time after c. $2.16 \mathrm{Ga}$ regional metamorphism. There are other Palaeoproterozoic sterane biomarker records. Dutkiewicz et al. (2006) and George et al. (2008) found them in sediments of the basal Huronian Supergroup (c. $2.4 \mathrm{Ga}$ ), with a signal that pre-dates $c .1 .9 \mathrm{Ga}$ Penokean metamorphism, and Dutkiewicz et al. (2007) discovered them in the 
c. 2.1 Ga Francevilian series of Gabon, with a signal that pre-dates supercritcality of the Oklo natural nuclear reactor at $1.95 \pm 0.04 \mathrm{Ga}$ (Gauthier-Lafaye \& Weber 2003).

Waldbauer et al. (2009) conducted a benchmark study in attempts to demonstrate the syngeneity of their observed sterane biomarker signal, obtained from $c$. 2.65-2.45 Ga strata in South Africa. The molecular fossils are described as pre-metamorphic, and vary according to sedimentary facies in correlative sections from adjacent drillcores. Nonetheless, the carbonate formations in those drillcores have been pervasively remagnetized at about 2.2$2.1 \mathrm{Ga}$ (de Kock et al. 2009), indicating basinwide low-grade hydrothermal fluid infiltration-at the same age within error as, and possibly in direct palaeogeographic proximity to, the regional metamorphic event on the adjacent Pilbara craton as described by Rasmussen et al. (2008).

We return to the Palaeoproterozoic glacial deposits, which are classically used to infer the palaeoenvironmental conditions in which these biological innovations occurred. Following an almost entirely ice-free Archaean history, the Palaeoproterozoic world was exposed to at least three ice ages, which appear to have penetrated deep into the tropics (Evans et al. 1997, global constraints reviewed by Evans 2003). These ice ages, lesser known but seemingly of equal severity to their more widely publicized Neoproterozoic 'snowball Earth' counterparts (Hoffman \& Schrag 2002), are generally rather poorly constrained in age to within the interval $2.45-2.22 \mathrm{Ga}$. As with the Neoproterozoic ice ages, estimating the number of Palaeoproterozoic glaciations is complicated by the fact that the diamictites themselves are commonly the principal items of correlation among cratons through this interval (e.g. Aspler \& Chiarenzelli 1998; Bekker et al. 2006).

The end of the second among three ice ages, recorded in the Huronian succession and correlative strata in Wyoming, is marked by a ${ }^{13} \mathrm{C}$-depleted "cap carbonate' unit that may be broadly comparable to those better developed after Neoproterozoic ice ages (Bekker et al. 2005). The South African sections contain two distinct sequences of diamictite and overlying ${ }^{13} \mathrm{C}$-depleted carbonate (Bekker et al. 2001), unconformably overlain by a third diamictite, the Makganyene Formation, in turn overlain by flood basalt and variably Mn-rich carbonate and ironstone units (Kirschvink et al. 2000) with nearzero $\delta^{13} \mathrm{C}$ values (Bau et al. 1999). Palaeomagnetic data from the flood basalt indicates deep tropical palaeolatitudes, constituting the best evidence of its kind for a Palaeoproterozoic snowball Earth event (Evans et al. 1997; Kirschvink et al. 2000; Evans 2003). Within the limits of existing age constraints, the Makganyene ice age could be correlative with the uppermost Huronian glaciation at $2.23 \mathrm{Ga}$ (Bekker et al. 2006), or, all three Huronian glacial levels could be distinctly older (Kopp et al. 2005). Given that the Lomagundi-Jatuli positive carbon-isotope excursion(s) began as early as $2.32 \mathrm{Ga}$, the near-zero $\delta^{13} \mathrm{C}$ values in the postMakganyene carbonate units are anomalously negative and warrant comparison with other Proterozoic postglacial cap carbonate sequences. Considering the high greenhouse forcing required to offset the Palaeoproterozoic 'faint young Sun' (Sagan \& Mullen 1972), escape from any 'snowball' climate regime of that age would have required tens of millions of years of volcanic outgassing uncompensated by silicate weathering (Tajika 2003). If all of the Palaeoproterozoic glacial deposits represent so-called 'hard' snowball ice ages, then Earth's panglacial climate mode would have occupied a substantial fraction of time in the 2.45-2.22 Ga interval.

As discussed above, the disappearance of non-mass-dependent sulphur isotope fractionation and the onset of highly ${ }^{13} \mathrm{C}$-enriched carbonates of the Lomagundi isotopic event are both located stratigraphically within the broad age range of these glaciations. More precisely, if the Bekker et al. (2006) correlations between North America and South Africa are correct, then the oldest carbonate-capped glacial deposits (Bruce and Rooihoogte Formations) constitute the stratigraphical boundary between two fundamentally distinct states of Earth's palaeoenvironment. Closely below this level are the final vestiges of detrital pyrite/uraninite deposition (Roscoe 1973) and non-mass-dependent sulphur isotope fractionation (Papineau et al. 2007). Closely above the level are the entirely mass-dependent-fractionated pyrites of the Timeball Hill Formation, dated at $2.32 \mathrm{Ga}$ and representing the rise of atmospheric oxygen (Bekker et al. 2004; Hannah et al. 2004) and the oldest carbonates with strongly enriched ${ }^{13} \mathrm{C}$ values indicating the onset of the Lomagundi-Jatuli isotopic excursions (Bekker et al. 2001). Glacial deposits with cap carbonates thus appear to be closely related to the rise of atmospheric oxygen. Collapse of the methane-rich, pre-2.4-Ga greenhouse due to atmospheric oxygenation (see above and Kasting 2005) could well be a trigger for the low-latitude ice ages, perhaps in addition to the silicate weathering removal of carbon dioxide due to the widespread and largely subaerial large igneous provinces at $2.45 \mathrm{Ga}$ (Melezhik 2006; Kump \& Barley 2007). But the ice ages themselves could also have contributed further to rapid pulses of oxygen production: Liang and co-workers (Liang et al. 2006) postulated the mechanism of hydrogen peroxide trapping in ice throughout the duration of a 'hard' snowball stage, which would be released suddenly to the oceans upon deglaciation. 
This glaciation-oxygenation scenario has been developed further, as reviewed by Kirschvink \& Kopp (2008). In that model, the hydrogen peroxide plume into the oceans upon panglacial melting would constitute the evolutionary driver of intracellular oxygen-mediating enzymes, which are seen as a necessary precursor to oxygenic photosynthesis. The post-Makganyene sequence, extraordinarily rich in $\mathrm{Mn}$, would represent the final and irreversible oxidation of the deep oceans (Kirschvink et al. 2000). Two outstanding problems with the timing of the model are as follows: (1) the Lomagundi-Jatuli positive isotopic excursion, apparently requiring burial of photosynthetically produced organic carbon, is found in preMakganyene strata (Bekker et al. 2001); and (2) increasingly more rigorous biomarker studies provide compelling evidence for photosynthetic organisms as old as $2.7 \mathrm{Ga}$ (e.g. Eigenbrode et al. 2008; Waldbauer et al. 2009).

Following the well known 2.45-2.2 Ga ice ages, the next nearly 1.5 billion years has traditionally been noted as entirely ice-free (Evans 2003). Recent documentation of periglacial features at c. $1.8 \mathrm{Ga}$ (Williams 2005) contests this conclusion. Nonetheless, the dominant climate state was nonglacial throughout most of PalaeoproterozoicMesoproterozoic time. Even in a mildly oxygenated, post-GOE atmosphere, methane is increasingly favoured as a minor but powerful greenhouse gas to combat the low luminosity of the Mesoproterozoic Sun (Pavlov et al. 2003; Kasting 2005; Kah \& Riding 2007).

\section{Extra-terrestrial influences: bolides and Earth-Moon orbital dynamics}

The two largest known bolide impact craters on Earth are Palaeoproterozoic in age, their sizes eclipsing that of the end-Cretaceous Chicxulub structure (Earth-Impact-database 2009). The largest, Vredefort in South Africa, is dated at $2.02 \mathrm{Ga}$; the second-largest, Sudbury, has an age of $1.85 \mathrm{Ga}$ (both impacts reviewed by Grieve \& Therriault 2000). No ejecta blanket has been discovered from Vredefort, but three regions of ejecta localities within 500-800 km from Sudbury are now reported (Addison et al. 2005; Pufahl et al. 2007). An impact spherule-bearing locality on the Nain or North Atlantic craton (Chadwick et al. 2001) has age constraints of 1.88-1.85 Ga (Garde et al. 2002), barely within range of the Sudbury event. The palaeogeographic proximity of Nain craton to the Sudbury impact site on Superior craton is unknown at $1.85 \mathrm{Ga}$ (Wardle et al. 2002). In addition to these two largest craters, Figure 1s shows three smaller ( $\geq 30 \mathrm{~km}$ diameter) craters in the 3.0-1.2 Ga time interval: Yarrabubba at an unknown age younger than its $c .2 .65 \mathrm{Ga}$ target rocks (Macdonald et al. 2003), Keurusselkä at an unknown age younger than its c. $1.88 \mathrm{Ga}$ target rocks (Hietala et al. 2004) and Shoemaker with a maximum age of $1.63 \mathrm{Ga}$ (Pirajno et al. 2003, 2009).

As there are no older preserved impact craters than c. $2.4 \mathrm{Ga}$ (Earth impact database 2009), all knowledge of prior impact history must be inferred from the lunar record, or determined from ejecta beds containing either spherules (Simonson \& Glass 2004) or anomalous concentrations of siderophile elements (Glikson 2005). For the time interval investigated here, the most prominent impact record is found in the sedimentary cover of the Vaalbara supercraton. At least three distinct spherule beds can be recognized; some readily correlated between Australia and South Africa, within the interval 2.63-2.49 Ga (Simonson et al. 2009). It is unknown what effects these impacts, undoubtedly a small subset of the total Archaean-Palaeoproterozoic bolide flux to the Earth, had on the ancient surface environment. Completion of the IGCP509 global stratigraphic database (Eglington et al. 2009) will help identify suitable sedimentary basins for finding ejecta blankets from the large craters described above.

The orbital parameters of Earth and the Moon can be gleaned from the sedimentary record of tidal rhythmites, which are usually in fine-grained mudstones and siltstones (e.g. Williams 2000). They can also be found in sandstone crossbed foresets (Mazumder 2004; Mazumder \& Arima 2005), including the oldest rhythmites in the geological record at c. $3.2 \mathrm{Ga}$ (Eriksson \& Simpson 2000). The most complete calculation of orbital parameters from tidal rhythmites can be found in Williams (2000), who listed two alternative calculations for the $2.45 \mathrm{Ga}$ Weeli Wolli banded iron formation in the Hamersley Ranges of Western Australia: one assuming that the lamina couplets (microbands) represented annual increments, the other assuming that they represented fortnightly cycles. Trendall (2002) has discussed how the annual microband model is consistent with $\mathrm{U}-\mathrm{Pb}$ age constraints through the Hamersley succession, and by implication, that the fortnightly alternative is not. The annual microband model predicts $17.1 \pm 1.1$ hours in the solar (Earth) day, $514 \pm 33$ solar days per year, and an EarthMoon distance of 51.9 \pm 3.3 Earth radii (compared to 60.27 at present) for the earliest Palaeoproterozoic (Williams 2000).

\section{Discussion}

The data summarized above and in Figure 1 provide an overview of secular changes in the Earth system from the Neoarchaean to Mesoproterozoic eras. Many of the relationships illustrated by two or 
three strands of data have been noted previously. In this overview, we have attempted to compile the first comprehensive summary of the secular changes from Earth's core to atmosphere over the Palaeoproterozoic supercontinent cycle, and the data reveal intriguing temporal relationships between changes in deep Earth and its surface environment.

Many of the physical models used to extrapolate modern planetary dynamics back into deep time suffer from the necessary simplifications of tractability, and many of the historical data proxies are incomplete or contentious. However, an emphasis on interdisciplinary Earth-system science has led to multiple working hypotheses for the interrelationships among the various proxy records, and we are particularly inspired by the following 10 recent developments.

1) Analytical and numerical models of Earth's thermal history and mantle convection are approaching the ability to generate plate tectonics self-consistently and to account for distinct geochemical reservoirs. These have potential to solve several long-troublesome paradoxes of geophysics and geochemistry.

2) Improved laboratory calibration of the perovskite to post-perovskite transition has refined temperature estimates at the core-mantle boundary, which will provide a better 'initial' boundary condition for such thermal evolution models (and also constrain core heat loss and thus geodynamo history). The geodynamic and geochemical consequences of the associated $\mathrm{D}^{\prime \prime}$ layer are likely to play critical roles in future models of Earth's thermal history and core-mantle interaction.

3) Resolution of the historical plume flux by a focused and global campaign to date mafic large igneous provinces (LIPs) will provide valuable constraints on mantle evolution, and will facilitate accurate pre-Pangaean continental reconstructions and a record of supercontinent amalgamation and dispersal that will in turn provide templates for mineral deposit belts and the development of new tectonic models.

4) An abrupt increase in the proportion of subaerial versus subaqueous LIP deposits at the Archaean-Proterozoic transition adds another indication of widespread continental emergence at that time; the temporal distribution of various types of iron formations can be understood better in the context of that transition.

5) The termination of non-mass-dependent fractionation of sulphur isotopes is now constrained to between 2.4 and $2.32 \mathrm{Ga}$, providing a robust stratigraphical marker by which all other proxies can be compared. Prior to this marker event, atmospheric oxygen levels were below
$10^{-5}$ of present atmospheric levels, a largely non-glacial world was kept warm by a substantial methane greenhouse effect, marine sulphate levels were low and halite evaporites followed directly after carbonate precipitation. Hydrothermal iron from the deep oceans upwelled onto the recently stabilized continental shelves to produce the vast Hamersley-type banded iron formations. After the marker event, oxygen levels rose to an unspecified level that generated Earth's oldest lateritic palaeosols, at least two ice ages occurred (one with cap carbonates and negative ${ }^{13} \mathrm{C}$ excursions, the other demonstrably extending to tropical palaeolatitudes), sulphate evaporites became abundant, and the background state of marine carbon isotopes became highly enriched as the unparalleled Lomagundi-Jatuli positive excursion.

6) The stratified, sulphidic-ocean model for $1.8-$ $0.8 \mathrm{Ga}$ has passed several geochemical and palaeoecological tests.

7) Further recognition of impact spherule beds provides a new strategy for evaluating Earth's impact history prior to the age of its largest and oldest (well dated) preserved crater (Vredefort, $2.02 \mathrm{Ga}$ ).

8) Despite warranted caution concerning both modern and ancient possible contamination of molecular fossils extracted from drillcores, some recent studies provide impressive benchmarks for testing the syngeneity of ancient biomarker records.

9) The two alleged Palaeoproterozoic animal fossil occurrences, uncomfortably more than a billion years older than the most reliable molecular clock studies would indicate, are now both explained by non-metazoan microbial processes.

10) Development of a global stratigraphic database for the Palaeoproterozoic era (Eglington et al. 2009), as a final product of the IGCP Project 509 , will allow ready correlation of rock units and tectonic settings across the world's cratons, which will be useful to researchers across all these proxy records of planetary evolution through Earth's post-Archaean transition.

Among many of the solid-Earth proxies shown in Figure 1, an important event occurred at c. 2.7 Ga. These include an abrupt increase in geodynamo palaeointensity (Fig. 1a), an unrivalled peak in the global LIP record (Fig. 1c), especially when scaled for preserved continental area by age, a broad maximum in several mantle depletion proxies (Fig. 1d), a strong peak in juvenile continental crust production (Fig. 1g), and a 'bonanza' of orogenic gold, massive-sulphide and porphyry copper deposits (Fig. 1j). It is tempting to link these 
records together in a model of enhanced mantle convection, perhaps due to a series of mantle plumes (Barley et al. 1998), slab avalanches (Condie 1998), or both. Stabilization of cratonic lithosphere was widespread from 2.7 to $2.5 \mathrm{Ga}$ (Bleeker 2003), and the consequent emergence of continents (Fig. 1f, 1) and expansion of sedimentary basins at their margins created accommodation space for the accumulation of voluminous banded ironformations (Fig. 1k) and flourishing of photosynthetic life (Fig. 1t). The latter development, at about $2.3 \mathrm{Ga}$, led to irreversible atmospheric oxidation (Fig. 1o, p), possibly dissipating a former methane greenhouse atmosphere and ushering in the extensive Palaeoproterozoic ice ages (Fig. 1r). Extreme events in global carbon cycling appear at this time (Fig. 1m). After the great oxidation event, marine sulphate levels rose (Fig. 1n), sediment-hosted and iron-oxide-rich metal deposits became abundant (Fig. 1j), and the transition to sulphide-stratified oceans (Fig. 1p) cradled early eukaryotic macrofossils (Fig. 1t).

Supercontinents may indeed be the centrepiece of the long-term Earth system, but their history is one of the least constrained elements in Figure 1. Nonetheless, there is hope for eventual understanding. New isotopic methods for precise geochronological calibration of deep time have made these comparisons possible. The stratigraphies of most of the world's Precambrian cratons are now increasingly constrained by acquisition of such precise rock ages, and there is no sign of slowing. Dedicated global working groups such as IGCP projects have fostered frequent, direct communication among researchers around the world. An emphasis on interdisciplinary science has led to multiple working hypotheses for the interrelationships among the various proxy records.

From core to surface, our next major advances will likely arise through determining accurate ways to measure ancient geomagnetic field strength; obtaining more complete records of mantle plume activity; developing novel methods for estimating crustal growth and continental emergence; solving the palaeogeography of supercontinents and supercratons, with consequent 'ground-truthing' of proposed tectonic processes and mineral deposit evolution; creating new chemical and isotopic proxies for the evolution of mantle, crust, and surface; dating these records precisely with new analytical techniques; and integrating these strands of data into robust geodynamic models. With these continuing advancements the ArchaeanProterozoic transition is at last coming into focus.

We thank Brendan Murphy and Alan Vaughan for formal manuscript reviews; and Alan Collins, Paul Hoffman, Jim Kasting, Rajat Mazumder, and Bruce Simonson for informal discussions. This work is a contribution to UNESCO's International Geoscience Programme (IGCP) Project 509 and is TIGeR publication No. 165.

\section{References}

Аввотт, D. H. \& IsLEy, A. E. 2002. The intensity, occurrence, and duration of superplume events and eras over geological time. Journal of Geodynamics, 34, 265-307.

Аввотt, D., Burgess, L., Longhi, J. \& SMith, W. H. F. 1994. An empirical thermal history of the Earth's upper mantle. Journal of Geophysical Research, 99, 13835-13850.

Addison, W. D., Brumpton, G. R. ET AL. 2005. Discovery of distal ejecta from the 1850 Ma Sudbury impact event. Geology, 33, 193-196.

Allegre, C. J. \& Rousseau, D. 1984. The growth of the continent through geological time studied by $\mathrm{Nd}$ isotope analysis of shales. Earth and Planetary Science Letters, 67, 19-34.

Allegre, C. J., Staudacher, T., SARda, P. \& Kurz, M. 1983. Constraints on evolution of Earth's mantle from rare gas systematics. Nature, 303, 762-766.

Anbar, A. D. \& KNOLL, A. H. 2002. Proterozoic ocean chemistry and evolution: a bioinorganic bridge? Science, 297, 1137-1142.

Anbar, A. D., DuAn, Y. ET aL. 2007. A whiff of oxygen before the Great Oxidation Event? Science, 317, 1903.

ANDERSON, D. L. 1994. Superplumes or supercontinents? Geology, 22, 39-42.

ARMSTRONG, R. L. 1981. Radiogenic isotopes: the case for crustal recycling on a near-steady-state nocontinental growth earth. Royal Society of London, Philosophical Transactions, Series A, 301, 443-472.

Armstrong, R. L. 1991. The persistent myth of crustal growth. Australian Journal of Earth Sciences, 38, 613-630.

ARndT, N. T. \& Goldstein, S. L. 1989. An open boundary between lower continental crust and mantle: its role in crust formation and crustal recycling. Tectonophysics, 161, 201-212.

Arnold, G. L., Anbar, A. D., BARling, J. \& Lyons, T. W. 2004. Molybdenum isotope evidence for widespread anoxia in mid-Proterozoic oceans. Science, 304, 87-90.

Aspler, L. B. \& Chiarenzelli, J. R. 1998. Two Neoarchean supercontinents? Evidence from the Paleoproterozoic. Sedimentary Geology, 120, 75-104.

Barley, M. E. \& Groves, D. I. 1992. Supercontinent cycles and the distribution of metal deposits through time. Geology, 20, 291-294.

Barley, M. E., Krapez, B., Groves, D. I. \& Kerrich, R. 1998. The Late Archaean bonanza: metallogenic and environmental consequences of the interaction between mantle plumes, lithospheric tectonics and global cyclicity. Precambrian Research, 91, 65-90.

BArley, M. E., BeKker, A. \& Krapez, B. 2005. Late Archean to Early Paleoproterozoic global tectonics, environmental change and the rise of atmospheric oxygen. Earth and Planetary Science Letters, 238, $156-171$. 
BAu, M., Romer, R. L., Luders, V. \& Beukes, N. J. 1999. $\mathrm{Pb}, \mathrm{O}$, and $\mathrm{C}$ isotopes in silicified Mooidraai dolomite (Transvaal Supergroup, South Africa): implications for the composition of Paleoproterozoic seawater and 'dating' the increase of oxygen in the Precambrian atmosphere. Earth and Planetary Science Letters, 174, 43-57.

Bekker, A., Kaufman, A. J., Karhu, J. A., Beukes, N. J., Swart, Q. D., Coetzee, L. L. \& Eriksson, K. A. 2001. Chemostratigraphy of the Paleoproterozoic Duitschland Formation, South Africa: implications for coupled climate change and carbon cycling. American Journal of Science, 301, 261-285.

BeKker, A., Holland, H. D. ET AL. 2004. Dating the rise of atmospheric oxygen. Nature, 427, 117-120.

BeKker, A., Kaufman, A. J., Karhu, J. A. \& ERIKsSON, K. A. 2005. Evidence for Paleoproterozoic cap carbonates in North America. Precambrian Research, 137, 167-206.

BeKker, A., Karhu, J. A. \& Kaufman, A. J. 2006. Carbon isotope record for the onset of the Lomagundi carbon isotope excursion in the Great Lakes area, North America. Precambrian Research, 148, $145-180$.

Bengtson, S., Rasmussen, B. \& Krapez, B. 2007. The Paleoproterozoic megascopic Stirling biota. Paleobiology, 33, 351.

Bennett, V. C. 2003. Compositional evolution of the mantle. In: CARLson, R. W. (ed.) The Mantle and Core. Treatise on Geochemistry. Elsevier/Pergamon, Oxford, 493-519.

BercovicI, D. 2003. The generation of plate tectonics from mantle convection. Earth and Planetary Science Letters, 205, 107-121.

Bercovici, D. \& Karato, S. 2003. Whole-mantle convection and the transition-zone water filter. Nature, 425, 39-44.

BERNER, R. A. 2006. GEOCARBSULF: a combined model for Phanerozoic atmospheric $\mathrm{O}_{2}$ and $\mathrm{CO}_{2}$. Geochimica et Cosmochimica Acta, 70, 5653-5664.

Berry, A. J., DANyushevsky, L. V., St. C. O'NeILl, H., New Ville, M. \& Sutton, S. R. 2008. Oxidation state of iron in komatiitic melt inclusions indicates hot Archaean mantle. Nature, 455, 960-963.

Betts, P. G. \& Giles, D. 2006. The $1800-1100$ Ma tectonic evolution of Australia. Precambrian Research, 144, 92-125.

BEUKES, N. J. \& GUTZMER, J. 2008. Origin and paleoenvironmental significance of major iron formations at the Archean-Paleoproterozoic boundary. Society of Economic Geologists Reviews, 15, 5-47.

Bispo-Santos, F., D'Agrella-Filho, M. S. ET $A L$. 2008. Columbia revisited: paleomagnetic results from the $1790 \mathrm{Ma}$ colider volcanics (SW Amazonian Craton, Brazil). Precambrian Research, 164, 40-49.

BJerrum, C. J. \& CANFIELD, D. E. 2002. Ocean productivity before about $1.9 \mathrm{Gyr}$ ago limited by phosphorus adsorption onto iron oxides. Nature, 417, 159.

BLEEKER, W. 2003. The late Archean record: a puzzle in ca. 35 pieces. Lithos, 71, 99-134.

BLEEKER, W. \& ERNST, R. 2006. Short-lived mantle generated magmatic events and their dyke swarms: the key unlocking Earth's palaeogeographic record back to
2.6 Ga. In: Hanski, E., Mertanen, S., RÄmÖ, T. \& Vuollo, J. (eds) Dyke Swarms-Time Markers of Crustal Evolution. Taylor \& Francis, London, 3-26.

Boussau, B., Blanquart, S., Necsulea, A., LartilLOT, N. \& GouY, M. 2008. Parallel adaptations to high temperatures in the Archaean eon. Nature, 456, 942-945.

Bradley, D. C. 2008. Passive margins through Earth history. Earth Science Reviews, 91, 1-26.

BRASIER, M. D., GREEN, O. R. ET AL. 2002. Questioning the evidence for Earth's oldest fossils. Nature, 416, $76-81$.

BRIMHALL, G. 1987. Preliminary fractionation patterns of ore metals through Earth history. Chemical Geology, 64, 1-16.

Brocks, J. J., Logan, G. A., Buick, R. \& Summons, R. E. 1999. Archean molecular fossils and the early rise of eukaryotes. Science, $\mathbf{2 8 5}, 1033$.

Brocks, J. J., Buick, R., Logan, G. A. \& Summons, R. E. 2003a. Composition and syngeneity of molecular fossils from the 2.78 to 2.45 billion-year-old Mount Bruce Supergroup, Pilbara Craton, Western Australia. Geochimica et Cosmochimica Acta, 67, 4289-4319.

Brocks, J. J., Buick, R., Summons, R. E. \& LogAn, G. A. 2003b. A reconstruction of Archean biological diversity based on molecular fossils from the 2.78 to 2.45 billion-year-old Mount Bruce Supergroup, Hamersley Basin, Western Australia. Geochimica et Cosmochimica Acta, 67, 4321-4335.

Brocks, J. J., Love, G. D., Summons, R. E., KNOLl, A. H., LogAN, G. A. \& Bowden, S. A. 2005. Biomarker evidence for green and purple sulphur bacteria in a stratified Palaeoproterozoic sea. Nature, 437, 866-870.

BRown, M. 2007. Metamorphic conditions in orogenic belts: a record of secular change. International Geology Review, 49, 193-234.

Buchan, K. L., Mortensen, J. K., Card, K. D. \& PerCIVAL, J. A. 1998. Paleomagnetism and U-Pb geochronology of diabase dyke swarms of Minto block, Superior Province, Quebec, Canada. Canadian Journal of Earth Sciences, 35, 1054.

Buchan, K. L., Goutier, J., Hamilton, M. A., ERnst, R. E. \& Matthews, W. A. 2007. Paleomagnetism, $\mathrm{U}-\mathrm{Pb}$ geochronology, and geochemistry of Lac Esprit and other dyke swarms, James Bay area, Quebec, and implications for Paleoproterozoic deformation of the Superior Province. Canadian Journal of Earth Sciences, 44, 643-664.

BUICK, I. S., UKEN, R., GIBSON, R. L. \& WALLMACH, T. 1998. High- $\delta{ }^{13} \mathrm{C}$ Paleoproterozoic carbonates from the Transvaal Supergroup, South Africa. Geology, 26, 875-878.

BUICK, R. 1992. The antiquity of oxygenic photosynthesis: evidence from stromatolites in sulphatedeficient Archaean lakes. Science, 255, 74-77.

Butler, S. L., Peltier, W. R. \& Costin, S. O. 2005. Numerical models of the Earth's thermal history: effects of inner-core solidification and core potassium. Physics of the Earth and Planetary Interiors, 152, 22-42.

BUtTERFIELD, N. J. 2000. Bangiomorpha pubescens n. gen., n. sp.: implications for the evolution of sex, multicellularity, and the Mesoproterozoic/Neoproterozoic radiation of eukaryotes. Paleobiology, 26, 386-404. 
Campbell, I. H. \& Allen, C. M. 2008. Formation of supercontinents linked to increases in atmospheric oxygen. Nature Geoscience, 1, 554-558.

CANFIEld, D. E. 1998. A new model for Proterozoic ocean chemistry. Nature a- $z$ index, 396, 450-453.

CANFIELD, D. E. 2005. The early history of atmospheric oxygen: Homage to Robert M. Garrels. Annual Reviews of Earth and Planetary Sciences, 33, 1-36.

Canfield, D. E., Poulton, S. W., Knoll, A. H., Narbonne, G. M., Ross, G., GoldberG, T. \& STRAuSs, H. 2008. Ferruginous conditions dominated later Neoproterozoic deep-water chemistry. Science, 321, 949.

Card, K. D. \& Poulsen, K. H. 1998. Geology and mineral deposits of the Superior Province of the Canadian Shield. In: LucAS, S. B. \& ST. OnGE, M. R. (co-ordinates) Geology of the Precambrian Superior and Grenville Provinces and Precambrian Fossils in North America. Geological Survey of Canada, Geology of Canada, 7, 13-194.

Catling, D. C. \& Claire, M. W. 2005. How Earth's atmosphere evolved to an oxic state: a status report. Earth and Planetary Science Letters, 237, 1-20.

Catling, D. C., Zahnle, K. J. \& MCKay, C. P. 2001. Biogenic methane, hydrogen escape, and the irreversible oxidation of early Earth. Science, 293, 839-843.

Cawood, P. A., Kröner, A. \& Pisarevsky, S. 2006. Precambrian plate tectonics: criteria and evidence. GSA Today, 16, 4-11.

Chadwick, B., Claeys, P. \& Simonson, B. 2001. New evidence for a large Palaeoproterozoic impact: spherules in a dolomite layer in the Ketilidian orogen, South Greenland. Journal of the Geological Society, 158, 331-340.

Chandler, F. W. \& Parrish, R. R. 1989. Age of the Richmond Gulf Group and implications for rifting in the Trans-Hudson Orogen, Canada. Precambrian Research, 44, 277-288.

Cheney, E. S. 1996. Sequence stratigraphy and plate tectonic significance of the Transvaal succession of southern Africa and its equivalent in Western Australia. Precambrian Research, 79, 3-24.

Cloud, P. E. 1968. Atmospheric and hydrospheric evolution on the primitive Earth. Science, 160, 729-736.

Collerson, K. D. \& Kamber, B. S. 1999. Evolution of the continents and the atmosphere inferred from $\mathrm{Th}-$ $\mathrm{U}-\mathrm{Nb}$ systematics of the depleted mantle. Science, 283, 1519.

CONDIE, K. C. 1995. Episodic ages of greenstones: a key to mantle dynamics? Geophysical Research Letters, 22, 2215-2218.

Condie, K. C. 1998. Episodic continental growth and supercontinents: a mantle avalanche connection? Earth and Planetary Science Letters, 163, 97-108.

CondIE, K. C. 2000. Episodic continental growth models: afterthoughts and extensions. Tectonophysics, 322, $153-162$.

Condie, K. C. 2004. Supercontinents and superplume events: distinguishing signals in the geologic record. Physics of the Earth and Planetary Interiors, 146, 319-332.

Condie, K. C. \& Kroner, A. 2008. When did plate tectonics begin? Evidence from the geologic record. In: Condie, K. C. \& Pease, V. (eds) When Did Plate
Tectonics Begin on Planet Earth? Geological Society of America Special Paper, 440, 281-294.

Condie, K. C. \& Pease, V. 2008. When Did Plate Tectonics Begin on Planet Earth? Geological Society of America Special Paper, 440.

Condie, K. C., O’Neill, C. \& Aster, R. C. 2009. Evidence and implications for a widespread magmatic shutdown for $250 \mathrm{My}$ on Earth. Earth and Planetary Science Letters, 282, 294-298.

Cruse, T. \& HARRIS, L. B. 1994. Ediacaran fossils from the Stirling Range Formation, Western Australia. Precambrian Research, 67, 1-10.

DAVIES, G. F. 1980. Thermal histories of convective Earth models and constraints on radiogenic heat production in the Earth. Journal of Geophysical Research, $\mathbf{8 5}$, 2517-2530.

DAVIES, G. F. 1988. Ocean bathymetry and mantle convection 1. Large-scale flow and hotspots. Journal of Geophysical Research, 93, 10451-10466.

DAviES, G. F. 1995. Penetration of plates and plumes through the mantle transition zone. Earth and Planetary Science Letters, 133, 507-516.

DAVIES, G. F. 2007. Mantle regulation of core cooling: a geodynamo without core radioactivity? Physics of the Earth and Planetary Interiors, 160, 215-229.

DE KocK, M. O., Evans, D. A. D. \& Beukes, N. J. 2009. Validating the existence of Vaalbara in the late Neoarchean. Precambrian Research, in press.

Dewey, J. F. \& Windley, B. F. 1981. Growth and differentiation of the continental crust. Philosophical Transactions of the Royal Society of London. Series A, Mathematical and Physical Sciences, 301, 189-206.

Dexter-Dyer, B., Kretzschmar, M. \& Krumbein, W. E. 1984. Possible microbial pathways in the formation of Precambrian ore deposits. Journal of the Geological Society, 141, 251-262.

Dutkiewicz, A., Volk, H., George, S. C., Ridley, J. \& BUICK, R. 2006. Biomarkers from Huronian oilbearing fluid inclusions: an uncontaminated record of life before the Great Oxidation Event. Geology, 34, 437-440.

Dutkiewicz, A., George, S. C., Mossman, D. J., RidLEY, J. \& VOLK, H. 2007. Oil and its biomarkers associated with the Palaeoproterozoic Oklo natural fission reactors, Gabon. Chemical Geology, 244, $130-154$.

EARTH IMPACt Database 2009. http://www.unb.ca/ passc/ImpactDatabase/. Accessed, 16 Feb 2009.

Eigenbrode, J. L., Freeman, K. H. \& Summons, R. E. 2008. Methylhopane biomarker hydrocarbons in Hamersley Province sediments provide evidence for Neoarchean aerobiosis. Earth and Planetary Science Letters, 273, 323-331.

Eriksson, K. A. \& Simpson, E. L. 1998. Controls on spatial and temporal distribution of Precambrian eolianites. Sedimentary Geology, 120, 275-294.

ERIKSSON, K. A. \& SiMPSON, E. L. 2000. Quantifying the oldest tidal record: The $3.2 \mathrm{Ga}$ Moodies Group, Barberton Greenstone Belt, South Africa. Geology, 28, 831-834.

Eriksson, K. A., Simpson, E. L., Master, S. \& HENRY, G. 2005a. Neoarchaean (c. $2.58 \mathrm{Ga}$ ) halite casts: implications for palaeoceanic chemistry. 
Journal of the Geological Society of London, 162, 789-799.

Eriksson, P. G., Catuneanu, O., Sarkar, S. \& TIRSGAARD, H. 2005 b. Patterns of sedimentation in the Precambrian. Sedimentary Geology, 176, 17-42.

Eriksson, P. G., Mazumder, R., Catuneanu, O., BumbY, A. J. \& ILONDO, B. O. 2006. Precambrian continental freeboard and geological evolution: a time perspective. Earth-Science Reviews, 79 $165-204$

ERNST, R. E. \& BUCHAN, K. L. 2001. Large mafic magmatic events through time and links to mantle-plume heads. In: ERNST, R. E. \& BUCHAN, K. L. (eds) Mantle Plumes: Their Identification Through Time. Geological Society of America Special Paper 352, Boulder, Colorado, 483-575.

ERnST, R. E. \& BUCHAN, K. L. 2003. Recognizing mantle plumes in the geological record. Annual Review of Earth and Planetary Sciences, 31, 469-523.

Evans, D. A. D. 2003. A fundamental PrecambrianPhanerozoic shift in earth's glacial style? Tectonophysics, 375, 353-385.

Evans, D. A. D. 2006. Proterozoic low orbital obliquity and axial-dipolar geomagnetic field from evaporite palaeolatitudes. Nature, 444, 51-55.

Evans, D. A. D. 2009. The palaeomagnetically viable, long-lived and all-inclusive Rodinia supercontinent reconstruction. In: MURPHY, J. B., KePPIE, J. D. \& Hynes, A. (eds) Ancient Orogens and Modern Analogues. Geological Society, London, Special Publications, 327, in press.

Evans, D. A., BeuKes, N. J. \& KirschvinK, J. L. 1997. Low-latitude glaciation in the Palaeoproterozoic era. Nature, 386, 262-266.

Evans, D. A. D. \& Pisarevsky, S. A. 2008. Plate tectonics on early Earth? Weighing the paleomagnetic evidence. In: CONDIE, K. C. \& PeAse, V. (eds) When Did Plate Tectonics Begin on Planet Earth? Geological Society of America, Special Paper, 440, 249-263.

FARQuhar, J., BaO, H. \& Thiemens, M. 2000. Atmospheric influence of Earth's earliest sulfur cycle. Science, 289, 756-758.

FArquhar, J., Peters, M., Johnston, D. T., Strauss, H., Masterson, A., Wiechert, U. \& Kaufman, A. J. 2007. Isotopic evidence for Mesoarchaean anoxia and changing atmospheric sulphur chemistry. Nature, 449, 706-709.

Fedonkin, M. A. \& Yochelson, E. L. 2002. Middle Proterozoic (1.5 Ga) Horodyskia moniliformis Yochelson and Fedonkin, the oldest known tissue-grade colonial eucaryote. Smithsonian Contributions to Paleobiology, 94, 1-29.

Fischer, A. G. 1984. The two Phanerozoic supercycles. In: Berggren, W. A. \& VAN Couvering, J. A. (eds) Catastrophes and Earth History. Princeton University Press, Princeton, 129-148.

Flament, N., Coltice, N. \& Rey, P. F. 2008. A case for late-Archaean continental emergence from thermal evolution models and hypsometry. Earth and Planetary Science Letters, 275, 326-336.

Fralick, P., Davis, D. W. \& Kissin, S. A. 2002. The age of the Gunflint Formation, Ontario, Canada: single zircon $\mathrm{U}-\mathrm{Pb}$ age determinations from reworked volcanic ash. Canadian Journal of Earth Sciences, 39, 1085-1091.

Garde, A. A., Chadwick, B., Grocott, J., Hamilton, M. A., MCCAfFrey, K. J. W. \& SWAGER, C. P. 2002. Mid-crustal partitioning and attachment during oblique convergence in an arc system, Palaeoproterozoic Ketilidian orogen, southern Greenland. Journal of the Geological Society, 159, 247-261.

GAstiL, R. G. 1960. The distribution of mineral dates in time and space. American Journal of Science, $\mathbf{2 5 8}, 1$.

Gauthier-Lafaye, F. \& Weber, F. 2003. Natural nuclear fission reactors: time constraints for occurrence, and their relation to uranium and manganese deposits and to the evolution of the atmosphere Precambrian Research, 120, 81-100.

Geoffrey, F. D. 1993. Cooling the core and mantle by plume and plate flows. Geophysical Journal International, 115, 132-146.

George, S. C., Dutkiewicz, A., Herbert, V., RidLEY, J. \& DAVID, J. 2008. Eukaryote-derived steranes in Precambrian oils and rocks: fact or fiction? Nature, 395, 885-888.

GLIKSON, A. Y. 2005. Geochemical signatures of Archean to Early Proterozoic Maria-scale oceanic impact basins. Geology, 33, 125-128.

Gonnermann, H. M., Manga, M. \& JellineK, A. M. 2002. Dynamics and longevity of an initially stratified mantle. Geophysical Research Letters, 29, 33-31.

Gower, C. F., Ryan, A. B. \& Rivers, T. 1990. Mid-Proterozoic Laurentia-Baltica: an overview of its geological evoluation and summary of contributions made by this volume. In: GOWER, C. F., RYAN, A. B. \& Rivers, T. (eds) Mid Proterozoic LaurentiaBaltica. GAC Special Paper 38. Geological Association of Canada, $1-22$.

GRAHAM, D. W. 2002. Noble gas isotope geochemistry of mid-ocean ridge and ocean island basalts: characterization of mantle source reservoirs. Reviews in Mineralogy and Geochemistry, 47, 247.

Grey, K., Williams, I. R., Martin, D. M. B., Fedonkin, M. A., Gehling, J. G., Runnegar, B. N. \& Yochelson, E. L. 2002. New occurrences of 'strings of beads' in the Bangemall Supergroup: a potential biostratigraphic marker horizon. Annual Report of the Geological Survey of West Australia, 69-73.

Grieve, R. \& Therriault, A. 2000. Vredefort, Sudbury, Chicxulub: Three of a Kind? Annual Review of Earth and Planetary Sciences, 28, 305-338.

Gross, G. A. 1965. Geology of iron deposits in Canada. 1, General geology and evaluation of iron deposits. Geological Survey of Canada.

Gross, G. A. 1983. Tectonic systems and the deposition of iron formation. Precambrian Research, 20 , $171-187$.

GRoTZINGER, J. P. 1989. Facies and evolution of Precambrian carbonate depositional systems: emergence of the modern platform archetype. In: CREVELLO, P. D., Wilson, J. L., Sarg, J. F. \& Read, J. F. (eds) Controls on Carbonate Platform and Basin Development. Society of Economic Paleontologists and Mineralogists, 44, Tulsa, 79-106. 
Grotzinger, J. P. \& JAmes, N. P. 2000. Precambrian carbonates: evolution of understanding. In: Grotzinger, J. P. \& JAmes, N. P. (eds) Carbonate Sedimentation and Diagenesis in the Evolving Precambrian World. Society for Sedimentary Geology Special Publications, 67, 3-22.

Grotzinger, J. P. \& Kasting, J. F. 1993. New constraints on Precambrian ocean composition. Journal of Geology, 101, 235-243.

Grotzinger, J. P. \& MCCORMick, D. S. 1988. Flexure of the Early Proterozoic lithosphere and the evolution of Kilohigok Basin $(1.9 \mathrm{Ga})$, northwest Canadian Shield. In: Kleinspehn, K. L. \& Paola, C. (eds) New Perspectives in Basin Analysis. Springer-Verlag, New York, 405-430.

Grove, T. L. \& PARMan, S. W. 2004. Thermal evolution of the Earth as recorded by komatiites. Earth and Planetary Science Letters, 219, 173-187.

Groves, D. I., Vielreicher, R. M., GoldFARb, R. J. \& Condie, K. C. 2005. Controls on the heterogeneous distribution of mineral deposits through time. In: McDonald, I., Boyce, A. J., Butler, I. B., Herrington, R. J. \& Polya, D. A. (eds) Mineral Deposits and Earth Evolution. Geological Society, London, Special Publications, 248, 71-101.

Gubbins, D., Masters, G. \& Nimmo, F. 2008. A thermochemical boundary layer at the base of Earth's outer core and independent estimate of core heat flux. Geophysical Journal International, 174, 1007-1018.

GURNIS, M. 1988. Large-scale mantle convection and the aggregation and dispersal of supercontinents. Nature, 332, 695-699.

Hale, C. J. 1987. Palaeomagnetic data suggest link between the Archaean-Proterozoic boundary and inner-core nucleation. Nature, 329, 233-237.

Halls, H. C., Davis, D. W., Stott, G. M., ERnst, R. E. \& Hamilton, M. A. 2008. The Paleoproterozoic Marathon Large Igneous Province: new evidence for a $2.1 \mathrm{Ga}$ long-lived mantle plume event along the southern margin of the North American Superior Province. Precambrian Research, 162, 327-353.

HAn, T. M. \& RunNegar, B. 1992. Megascopic eukaryotic algae from the 2.1-billion-year-old Negaunee iron-formation, Michigan. Science, 257, $232-235$.

Hannah, J. L., BeKker, A., Stein, H. J., Markey, R. J. \& Holland, H. D. 2004. Primitive Os and $2316 \mathrm{Ma}$ age for marine shale: implications for Paleoproterozoic glacial events and the rise of atmospheric oxygen. Earth and Planetary Science Letters, 225, 43-52.

Harrison, D. \& Ballentine, C. J. 2005. Noble gas models of mantle convection and mass reservoir transfer. In: VAN DER HiLst, R. D., BASS, J., MATAS, J. \& Trampert, J. (eds) Earth's Deep Mantle: Structure, Composition and Evolution. Geophysical Monograph, 160. American Geophysical Union, 9-26.

HAw KeSWORTH, C. J. \& KEMP, A. I. S. 2006a. Evolution of the continental crust. Nature, 443, 811-817.

Hawkesworth, C. J. \& Kemp, A. I. S. 2006b. Using hafnium and oxygen isotopes in zircons to unravel the record of crustal evolution. Chemical Geology, 226, 144-162.
Hawkesworth, C., Cawood, P., Kemp, T., Storey, C. \& Dhuime, B. 2009. Geochemistry: A Matter of Preservation. Science, 323, 49.

Hazen, R. M., Papineau, D., Bleeker, W. et al. 2008. Mineral evolution. American Mineralogist, 93, 1693.

Heaman, L. M. 1997. Global mafic magmatism at $2.45 \mathrm{Ga}$ : remnants of an ancient large igneous province. Geology, 25, 299-302.

Hernlund, J. W., Thomas, C. \& Tackley, P. J. 2005. A doubling of the post-perovskite phase boundary and structure of the Earth's lowermost mantle. Nature, 434, 882-886.

Hietala, S., Moilanen, J. \& Kivelantie, B. 2004. Keurusselkä -a new impact structure in central Finland. In: 35th Lunar and Planetary Science Conference Abstract, March 15-19. League City, Texas.

Hilton, D. R. \& Porcelli, D. 2003. Noble gases as mantle tracers. Treatise on Geochemistry, 2.

Hirose, K., FeI, Y., MA, Y. \& MAO, H. K. 1999. The fate of subducted basaltic crust in the Earth's lower mantle. Nature, 397, 53-56.

HiRose, K. \& LAY, T. 2008. Discovery of post-perovskite and new views on the core-mantle boundary region. Elements, 4, 183-189.

Hirth, G. \& Kohlstedt, D. L. 1996. Water in the oceanic upper mantle: implications for rheology, melt extraction and the evolution of the lithosphere. Earth and Planetary Science Letters, 144, 93-108.

HofFMAN, P. F. 1988. United plates of America, the birth of a craton: early proterozoic assembly and growth of laurentia. Annual Reviews of Earth and Planetary Sciences, 16, 543-603.

Hoffman, P. F. 1989. Speculations on Laurentia's first gigayear (2.0 to $1.0 \mathrm{Ga})$. Geology, 17, 135-138.

HofFMAN, P. F. 1997. Tectonic genealogy of North America. In: VAN DER PluiJM, B. A. \& MARshaK, S. (eds) Earth Structure: An Introduction to Structural Geology and Tectonics. New York, McGraw-Hill, 459-464.

Hoffman, P. F. \& Schrag, D. P. 2002. The snowball Earth hypothesis: testing the limits of global change. Terra Nova, 14, 129-155.

HofmanN, A. W. 2003. Sampling mantle heterogeneity through oceanic basalts: isotopes and trace elements. Treatise on Geochemistry, 2, 61-101.

HofmanN, H. J. 1976. Precambrian microflora, Belcher Islands, Canada: significance and systematics. Journal of Paleontology, 50, 1040-1073.

Holland, H. D. 2002. Volcanic gases, black smokers, and the Great Oxidation Event. Geochimica et Cosmochimica Acta, 66, 3811-3826.

Holland, H. D. 2006. The oxygenation of the atmosphere and oceans. Philosophical Transactions of the Royal Society B: Biological Sciences, 361, 903-915.

Hou, G., SAntosh, M., QIAN, X., Lister, G. S. \& Li, J. 2008a. Configuration of the Late Paleoproterozoic supercontinent Columbia: insights from radiating mafic dyke swarms. Gondwana Research, 14, 395-409.

Hou, G., Santosh, M., Qian, X., Lister, G. S. \& Li, J. 2008b. Tectonic constraints on, $1.3-1.2 \mathrm{Ga}$ final breakup of Columbia supercontinent from a giant radiating dyke swarm. Gondwana Research, 14, 561-566. 
HuRLEY, P. M. \& RAND, J. R. 1969. Pre-drift continental nuclei. Science, 164, 1229-1242.

Huston, D. L. \& LogAn, G. A. 2004. Barite, BIFs and bugs: evidence for the evolution of the Earth's early hydrosphere. Earth and Planetary Science Letters, 220, 41-55.

HYNES, A. 2001. Freeboard revisited: continental growth, crustal thickness change and Earth's thermal efficiency. Earth and Planetary Science Letters, 185, $161-172$.

Isley, A. E. \& AввотT, D. H. 1999 Plume-related mafic volcanism and the deposition of banded iron formation. Journal of Geophysical Research, 104, 15461-15477.

JACOBS, J. A. 1953. The Earth's Inner Core. Nature, 172, 297-298.

JACobsen, S. B. \& WASSERburg, G. J. 1979. Mean age of mantle and crustal reservoirs. Journal of Geophysical Research, 84, 7411-7428.

Jaupart, C., Labrosse, S., Mareschal, J. C. \& GERALD, S. 2007. Temperatures, Heat and Energy in the Mantle of the Earth. Treatise on Geophysics. Elsevier, Amsterdam, 253-303.

JEANLOZ, R. 1990. The nature of the Earth's core. Annual Review of Earth and Planetary Sciences, 18, 357-386.

KAH, L. C. \& RIDING, R. 2007. Mesoproterozoic carbon dioxide levels inferred from calcified cyanobacteria. Geology, 35, 799.

KAH, L. C., LyONS, T. W. \& FranK, T. D. 2004. Low marine sulphate and protracted oxygenation of the Proterozoic biosphere. Nature, 431, 834-838.

KARHU, J. A. \& Holland, H. D. 1996. Carbon isotopes and the rise of atmospheric oxygen. Geology, 24, $867-870$

Kasting, J. F. 2005. Methane and climate during the Precambrian era. Precambrian Research, 137, 119-129.

Kasting, J. F., Eggler, D. H. \& RAeburn, S. P. 1993. Mantle redox evolution and the oxidation state of the Archean atmosphere. Journal of Geology, 101, 245-257.

Kaufman, A. J., Johnston, D. T. ET AL. 2007. Late Archean biospheric oxygenation and atmospheric evolution. Science, 317, 1900.

Kellogg, L. H., HAGER, B. H. \& VAN DER Hilst, R. D. 1999. Compositional stratification in the deep mantle. Science, 283, 1881-1884.

Kemp, A. I. S., Hawkesworth, C. J., Paterson, B. A. \& KINNY, P. D. 2006. Episodic growth of the Gondwana supercontinent from hafnium and oxygen isotopes in zircon. Nature, 439, 580-583.

Kemp, A. I. S., Hawkesworth, C. J. ET AL. 2007. Magmatic and crustal differentiation history of granitic rocks from Hf-O isotopes in zircon. Science, 315, 980 .

KIRSCHVINK, J. L. 1992. Late Proterozoic low-latitude global glaciation: the Snowball Earth. In: SCHOPF, W. S. \& KLeIn, C. (eds) The Proterozoic Biosphere. Cambridge University Press, Cambridge, 51-52.

KirschVinK, J. L. \& KopP, R. E. 2008. Palaeoproterozoic ice houses and the evolution of oxygen-mediating enzymes: the case for a late origin of photosystem II. Philosophical Transactions of the Royal Society B: Biological Sciences, 363, 2755-2765.

Kirschvink, J. L., Gaidos, E. J., Bertani, L. E., Beukes, N. J., Gutzmer, J., Maepa, L. N. \&
Steinberger, R. E. 2000. Paleoproterozoic snowball Earth: extreme climatic and geochemical global change and its biological consequences. Proceedings of the National Academy of Sciences, 97, 1400-1405.

KLEIN, C. 2005. Some Precambrian banded ironformations (BIFs) from around the world: Their age, geologic setting, mineralogy, metamorphism, geochemistry, and origins. American Mineralogist, 90, 1473-1499.

Klein, C. \& Beukes, N. J. 1992. Time distribution, stratigraphy, and sedimentologic setting, and geochemistry of Precambrian iron-formations. In: Schopf, J. W. \& KLeIn, C. (eds) The Proterozoic Biosphere: A Multidisciplinary Study. Cambridge University Press, Cambridge, 139-146.

KNAUTH, L. P. 2005. Temperature and salinity history of the Precambrian ocean: implications for the course of microbial evolution. Palaeogeography Palaeoclimatology Palaeoecology, 219, 53-69.

Knauth, L. P. \& Lowe, D. R. 2003. High Archean climatic temperature inferred from oxygen isotope geochemistry of cherts in the $3.5 \mathrm{Ga}$ Swaziland Supergroup, South Africa. Bulletin of the Geological Society of America, 115, 566-580.

Knoll, A. H., Javaux, E. J., Hewitt, D. \& Cohen, P. 2006. Eukaryotic organisms in Proterozoic oceans. Philosophical Transactions of the Royal Society B: Biological Sciences, 361, 1023-1038.

KomiYA, T. 2004. Material circulation model including chemical differentiation within the mantle and secular variation of temperature and composition of the mantle. Physics of the Earth and Planetary Interiors, 146, 333-367.

Konhauser, K. O., Lalonde, S. V., Amskold, L. \& Holland, H. D. 2007. Was there really an Archean phosphate crisis? Science, 315, 1234.

Kopp, R. E., Kirschvink, J. L., Hilburn, I. A. \& NASH, C. Z. 2005. The Paleoproterozoic snowball Earth: a climate disaster triggered by the evolution of oxygenic photosynthesis. Proceedings of the National Academy of Sciences, 102, 11131-11136.

Korenaga, J. 2006. Archean geodynamics and the thermal evolution of Earth. In: BENN, K., Mareschal, J.-C. \& Condie, K. C. (eds) Archean Geodynamics and Environments. Geophysical Monograph 164, American Geophysical Union, Washington, D.C, 7-32.

KorenagA, J. 2008a. Comment on 'Intermittent Plate Tectonics?' Science, 320, 1291a.

KorenagA, J. 2008b. Invited review Plate tectonics, flood basalts and the evolution of Earth's oceans. Terra Nova, 20, 419-439.

Korenaga, J. 2008c. Urey ratio and the structure and evolution of Earth's mantle. Reviews of Geophysics, 46; doi: 10.1029/2007RG000241.

KRAPEZ, B. 1999. Stratigraphic record of an Atlantic-type global tectonic cycle in the Palaeoproterozoic Ashburton Province of Western Australia. Australian Journal of Earth Sciences, 46, 71-87.

KUMP, L. R. \& B ARLEY, M. E. 2007. Increased subaerial volcanism and the rise of atmospheric oxygen 2.5 billion years ago. Nature, 448, 1033-1036.

KUMP, L. R., KASTING, J. F. \& B ARLEY, M. E. 2001. Rise of atmospheric oxygen and the 'upside-down' Archean 
mantle. Geochemistry Geophysics Geosystems, 2, $\mathrm{U} 1-\mathrm{U} 10$.

Labrenz, M., Druschel, G. K., Thomsen-Ebert, T. ET AL. 2000. Formation of sphalerite ( $\mathrm{ZnS}$ ) deposits in natural biofilms of sulfate-reducing bacteria. Science, 290, 1744-1747.

LABROSSE, S. \& JAUPART, C. 2007. Thermal evolution of the Earth: secular changes and fluctuations of plate characteristics. Earth and Planetary Science Letters, 260, 465-481.

Labrosse, S., Poirier, J. P. \& Le MouëL, J. L. 2001. The age of the inner core. Earth and Planetary Science Letters, 190, 111-123.

Labrosse, S., Hernlund, J. W. \& Coltice, N. 2007. A crystallizing dense magma ocean at the base of the Earth's mantle. Nature, 450, 866-869.

Ledru, P., Johan, V., Milesi, J. P. \& Tegyey, M. 1994. Markers of the last stages of the Palaeoproterozoic collision: evidence for a $2 \mathrm{Ga}$ continent involving circum-South Atlantic provinces. Precambrian Research, 69, 169-191.

Lepot, K., Benzerara, K., Brown, G. E. \& PHILIPPOT, P. 2008. Microbially influenced formation of, 2,724-million-year-old stromatolites. Nature Geoscience, 1, 118-121.

LI, Z. X. 2000. Palaeomagnetic evidence for unification of the North and West Australian cratons by ca.1.7 Ga: new results from the Kimberley Basin of northwestern Australia. Geophysical Journal International, 142, $173-180$.

Li, Z. X., Bogdanova, S. V. ET AL. 2008. Assembly, configuration, and break-up history of Rodinia: A synthesis. Precambrian Research, 160, 179-210.

Li, Z. X., Bogdanova, S. V. ET AL. 2009. How not to assemble a Precambrian supercontinent - Reply to comment by J. D. A. Piper on 'Assembly, configuration, and break-up history of Rodinia: A synthesis' by Li, Z. X., Bogdanova, S. V., ET AL. Precambrian Research, 160 (1-2), 179-210 (2008). Precambrian Research in press.

Liang, M. C., HARTMAN, H., Kopp, R. E., KirschVinK, J. L. \& YUNG, Y. L. 2006. Production of hydrogen peroxide in the atmosphere of a snowball earth and the origin of oxygenic photosynthesis. Proceedings of the National Academy of Sciences, 103, 18896.

LiNDSAY, J. F. \& BRASIER, M. D. 2002. Did global tectonics drive early biosphere evolution? Carbon isotope record from 2.6 to $1.9 \mathrm{Ga}$ carbonates of Western Australian basins. Precambrian Research, 114, 1-34.

LONG, D. G. F. 2006. Architecture of pre-vegetation sandy-braided perennial and ephemeral river deposits in the Paleoproterozoic Athabasca Group, northern Saskatchewan, Canada as indicators of Precambrian fluvial style. Sedimentary Geology, 190, 71-95.

LOWE, D. R. \& TICE, M. M. 2007. Tectonic controls on atmospheric, climatic, and biological evolution 3.5-2.4 Ga. Precambrian Research, 158, 177-197.

LOWMAN, J. P. \& JARVIS, G. T. 1999. Effects of mantle heat source distribution on supercontinent stability. Journal of Geophysical Research, 104, 12,733-712,746.

Macdonald, F. A., Bunting, J. A. \& Cina, S. E. 2003. Yarrabubba-a large, deeply eroded impact structure in the Yilgarn Craton, Western Australia. Earth and Planetary Science Letters, 213, 235-247.

Macouin, M., Valet, J. P., Besse, J., Buchan, K., ERnst, R., LeGofF, M. \& SCHARER, U. 2003. Low paleointensities recorded in 1 to $2.4 \mathrm{Ga}$ Proterozoic dykes, Superior Province, Canada. Earth and Planetary Science Letters, 213, 79-95.

Macouin, M., VAlet, J. P. \& Besse, J. 2004. Long-term evolution of the geomagnetic dipole moment. Physics of The Earth and Planetary Interiors, 147, 239-246.

Marshall, H., WALKer, J. \& KuHN, W. 1988. Longterm climate change and the geochemical cycle of carbon. Journal of Geophysical Research, 93.

MARTIN, D. M. B. 2004. Depositional environment and taphonomy of the'strings of beads': mesoproterozoic multicellular fossils in the Bangemall Supergroup, Western Australia. Australian Journal of Earth Sciences, 51, 555-561.

Matz, M. V., Frank, T. M., Marshall, N. J., WidDER, E. A. \& Johnsen, S. 2008. Giant deep-sea protist produces bilaterian-like traces. Current Biology, 18, 1849-1854.

MAZUMDER, R. 2004. Implications of lunar orbital periodicity from, the Chaibasa tidal rhythmite (India) of late Paleoproterozoic age. Geology, 32, 841-844.

MAZUMder, R. \& ARIMA, M. 2005. Tidal rhythmites and their implications. Earth Science Reviews, 69, 79-95.

McCulloch, M. T. \& Bennett, V. C. 1994. Progressive growth of the Earth's continental crust and depleted mantle: geochemical constraints. Geochimica et Cosmochimica Acta, 58, 4717-4738.

MCLENNAN, S. M. 1989. Rare earth elements in sedimentary rocks; influence of provenance and sedimentary processes. Reviews in Mineralogy and Geochemistry, 21, 169-200.

MeErT, J. G. 2002. Paleomagnetic evidence for a PaleoMesoproterozoic supercontinent Columbia. Gondwana Research, 5, 207-215.

MeERT, J. G. \& TorsviK, T. H. 2003. The making and unmaking of a supercontinent: Rodinia revisited. Tectonophysics, 375, 261-288.

Meert, J. G. \& Torsvik, T. H. 2004. Paleomagnetic constraints on Neoproterozoic 'Snowball Earth' continental reconstructions. In: JENKINS, G. S., McMenamin, M. A. S., McKay, C. P. \& Sohl, L. (eds) The Extreme Proterozoic: Geology, Geochemistry, and Climate. AGU Geophysical Monograph Series, 146, 5-11.

MeleZhiK, V. A. 2006. Multiple causes of Earth's earliest global glaciation. Terra Nova, 18, 130-137.

Melezhik, V. A., Fallick, A. E., Medvedev, P. V. \& MAKARIKHIN, V. V. 1999. Extreme ${ }^{13} \mathrm{C}_{\text {carb }}$ enrichment in ca. $2.0 \mathrm{Ga}$ magnesite-stromatolitedolomite-red beds' association in a global context: a case for the world-wide signal enhanced by a local environment. Earth-Science Reviews, 48, 71-120.

MelezhiK, V. A., Fallick, A. E., Hanski, E. J., KumP, L. R., Lepland, A., Prave, A. R. \& Strauss, H. 2005a. Emergence of an aerobic biosphere during the Archean-Proterozoic transition: challenges of future research. GSA Today, 15, 4-11.

MelezhiK, V. A., Fallick, A. E., RychanchiK, D. V. \& Kuznetsov, A. B. 2005b. Palaeoproterozoic 
evaporites in Fennoscandia: implications for seawater sulphate, the rise of atmospheric oxygen and local amplification of the delta C-13 excursion. Terra Nova, 17, 141-148.

Melezhik, V. A., Huhma, H., Condon, D. J., Fallick, A. E. \& Whitehouse, M. J. 2007. Temporal constraints on the Paleoproterozoic LomagundiJatuli carbon isotopic event. Geology, 35, 655.

Murakami, M., Hirose, K., Kawamura, K., Sata, N. \& OHISHI, Y. 2004. Post-perovskite phase transition in $\mathrm{MgSiO}_{3}$. Science, 304, 855-858.

Nance, R. D., Worsley, T. R. \& Moody, J. B. 1986. Post-Archean biogeochemical cycles and long-term episodicity in tectonic processes. Geology, 14, 514-518.

NANCE, R., Worsley, T. \& Moody, J. 1988. The supercontinent cycle. Scientific American, 259, 72-79.

Nimmo, F., Price, G. D., Brodholt, J. \& Gubbins, D. 2004. The influence of potassium on core and geodynamo evolution. Geophysical Journal International, 156, 363-376.

Noffke, N., Hazen, R. \& Nhleko, N. 2003. Earth's earliest microbial mats in a siliciclastic marine environment (2.9 Ga Mozaan Group, South Africa). Geology, 31, 673-676.

Noffke, N., Beukes, N., Gutzmer, J. \& Hazen, R. 2006a. Spatial and temporal distribution of microbially induced sedimentary structures: a case study from siliciclastic storm deposits of the $2.9 \mathrm{Ga}$ Witwatersrand Supergroup, South Africa. Precambrian Research, 146, 35-44.

Noffke, N., ERIKsson, K. A., Hazen, R. M. \& Simpson, E. L. 2006 b. A new window into Early Archean life: microbial mats in Earth's oldest siliciclastic tidal deposits (3.2 Ga Moodies Group, South Africa). Geology, 34, 253-256.

Noffke, N., Beukes, N., Bower, D., Hazen, R. M. \& SWIFT, D. J. P. 2008. An actualistic perspective into Archean worlds-(cyano-) bacterially induced sedimentary structures in the siliciclastic Nhlazatse Section, 2.9 Ga Pongola Supergroup, South Africa. Geobiology, 6, 5-20.

Nomade, S., Chen, Y. ET AL. 2003. The Guiana and the West African shield Palaeoproterozoic grouping: new palaeomagnetic data for French Guiana and the Ivory Coast. Geophysical Journal International, 154, 677-694.

O'Neill, C., Lenardic, A., JellineK, A. M. \& MORESI, L. 2009. Influence of supercontinents on deep mantle flow. Gondwana Research, 15, 276-287.

O'Nions, R. K. \& OxBurgh, E. R. 1983. Heat and helium in the Earth. Nature, 306, 429-431.

O’Nions, R. K., Evensen, N. M. \& Hamilton, P. J. 1979. Geochemical modeling of mantle differentiation and crustal growth. Journal of Geophysical Research, 84, 6091-6101.

OGAWA, M. 2008. Mantle convection: A review. Fluid Dynamics Research, 40, 379-398.

Ohmoto, H., Watanabe, Y., Ikemi, H., Poulson, S. R. \& TAYLOR, B. E. 2006. Sulphur isotope evidence for an oxic Archaean atmosphere. Nature, 442, 908.

Ono, S., Eigenbrode, J. L., Pavlov, A. A., Kharecha, P., Rumble, D., Kasting, J. F. \& Freeman, K. H. 2003. New insights into Archean sulfur cycle from mass-independent sulfur isotope records from the Hamersley Basin, Australia. Earth and Planetary Science Letters, 213, 15-30.

ONO, S., BEUKES, N. J. \& RUMBLE, D. 2009a. Origin of two distinct multiple-sulfur isotope compositions of pyrite in the 2.5 Ga Klein Naute Formation, Griqualand West Basin, South Africa. Precambrian Research, 169, 48-57.

Ono, S., Kaufman, A. J., Farquhar, J., Sumner, D. Y. \& BEUKES, N. J. 2009b. Lithofacies control on multiple-sulfur isotope records and Neoarchean sulfur cycles. Precambrian Research, 169, 58-67.

Onstott, T. C. \& Hargraves, R. B. 1981. Proterozoic transcurrent tectonics: palaeomagnetic evidence from Venezuela and Africa. Nature, 289, 131-136.

Onstott, T. C., Hargraves, R. B., York, D. \& HALL, C. 1984. Constraints on the motions of South American and African shields during the Proterozoic; $\mathrm{I}, 40 \mathrm{Ar} / 39 \mathrm{Ar}$ and paleomagnetic correlations between Venezuela and Liberia. Bulletin of the Geological Society of America, 95, 1045-1054.

Papineau, D., Mojzsis, S. J. \& SchmitT, A. K. 2007. Multiple sulfur isotopes from Paleoproterozoic Huronian interglacial sediments and the rise of atmospheric oxygen. Earth and Planetary Science Letters, 255, $188-212$

PARMAN, S. W. 2007. Helium isotopic evidence for episodic mantle melting and crustal growth. Nature, 446, 900-903.

Pavlov, A. A. \& Kasting, J. F. 2002. Mass-independent fractionation of sulfur isotopes in Archean sediments: strong evidence for an anoxic Archean atmosphere. Astrobiology, 2, 27-41.

Pavlov, A. A., Brown, L. L. \& Kasting, J. F. 2001. UV shielding of $\mathrm{NH}_{3}$ and $\mathrm{O}_{2}$ by organic hazes in the Archean atmosphere. Journal of Geophysical Research, 106, 23267-23287.

Pavlov, A. A., Hurtgen, M. T., Kasting, J. F. \& Arthur, M. A. 2003. Methane-rich Proterozoic atmosphere? Geology, 31, 87-90.

Pearson, D. G., Parman, S. W. \& Nowell, G. M. 2007. A link between large mantle melting events and continent growth seen in osmium isotopes. Nature, 449, 202-205.

Percival, J. A., Sanborn-Barrie, M., Skulski, T., Stott, G. M., Helmstaedt, H. \& White, D. J. 2006. Tectonic evolution of the western Superior Province from NATMAP and Lithoprobe studies. Canadian Journal of Earth Sciences, 43, 1085.

Pesonen, L. J., Elming, S. ET AL. 2003. Palaeomagnetic configuration of continents during the Proterozoic. Tectonophysics, 375, 289-324.

PIPER, J. D. A. 2003. Consolidation of continental crust in Late Archaean - Early Proterozoic times: a palaeomagnetic test. Gondwana Research, 6, 435-448.

PIPER, J. D. A. 2007. The Neoproterozoic supercontinent Palaeopangaea. Gondwana Research, 12, 202-227.

PIRAJNO, F. 2004. Hotspots and mantle plumes: global intraplate tectonics, magmatism and ore deposits. Mineralogy and Petrology, 82, 183-216.

Pirajno, F., Hawke, P., Glikson, A. Y., Haines, P. W. \& UYSAL, T. 2003. Shoemaker impact structure, Western Australia. Australian Journal of Earth Sciences, 50, 775-796. 
Pirajno, F., Hocking, R. M., Reddy, S. M. \& Jones, A. J. 2009. A review of the geology and geodynamic evolution of the Palaeoproterozoic Earaheedy Basin, Western Australia. Earth-Science Reviews, 94, 39-77.

PisAReVsky, S. A. \& NATAPOV, L. M. 2003. Siberia and Rodinia. Tectonophysics, 375, 221-245.

Pisarevsky, S. A., NAtapov, L. M., Donskaya, T. V., Gladkochub, D. P. \& Vernikovsky, V. A. 2008. Proterozoic Siberia: a promontory of Rodinia. Precambrian Research, 160, 66-76.

Plumb, K. A. 1991. New Precambrian time scale. Episodes, 14, 139-140.

Poller, U., Gladkochub, D., Donskaya, T., Mazukabzov, A., Sklyarov, E. \& Todt, W. 2005. Multistage magmatic and metamorphic evolution in the Southern Siberian Craton: Archean and Palaeoproterozoic zircon ages revealed by SHRIMP and TIMS. Precambrian Research, 136, 353-368.

Pope, M. C. \& GRotzinger, J. P. 2003. Paleoproterozoic Stark Formation, Athapuscow Basin, Northwest Canada: record of cratonic-scale salinity crisis. Journal of Sedimentary Research, 73, 280-295.

Porcelli, D. \& Ballentine, C. J. 2002. Models for distribution of terrestrial noble gases and evolution of the atmosphere. Reviews in Mineralogy and Geochemistry, 47, 411.

Porcelli, D. \& ElliotT, T. 2008. The evolution of He isotopes in the convecting mantle and the preservation of high ${ }^{3} \mathrm{He} /{ }^{4} \mathrm{He}$ ratios. Earth and Planetary Science Letters, 269, 175-185.

Prokoph, A., Ernst, R. E. \& Buchan, K. L. 2004. Time-series analysis of large igneous provinces: 3500 Ma to present. Journal of Geology, 112, 1-22.

Pufahl, P. K., Hiatt, E. E., Stanley, C. R., Morrow, J. R., Nelson, G. J. \& Edwards, C. T. 2007. Physical and chemical evidence of the 1850 Ma Sudbury impact event in the Baraga Group, Michigan. Geology, 35, 827.

Rasmussen, B., Bengtson, S., Fletcher, I. R. \& MCNaughton, N. J. 2002a. Discoidal impressions and trace-like fossils more than 1200 million years old. Science, 296, 1112-1115.

Rasmussen, B., Bose, P. K., Sarkar, S., Banerjee, S., Fletcher, I. R. \& MCNAughton, N. J. $2002 b$. $1.6 \mathrm{Ga} \mathrm{U}-\mathrm{Pb}$ zircon age for the Chorhat Sandstone, lower Vindhyan, India: possible implications for early evolution of animals. Geology, 30, 103-106.

Rasmussen, B., Fletcher, I. R., Bengtson, S. \& McNaughton, N. J. 2004. SHRIMP U-Pb dating of diagenetic xenotime in the Stirling Range Formation, Western Australia: 1.8 billion year minimum age for the Stirling biota. Precambrian Research, 133, 329-337.

Rasmussen, B., Fletcher, I. R., Brocks, J. J. \& KilbuRn, M. R. 2008. Reassessing the first appearance of eukaryotes and cyanobacteria. Nature, $\mathbf{4 5 5}$, 1101-1104.

Ray, J. S., Martin, M. W., Veizer, J. \& Bowring, S. A. 2002. U-Pb zircon dating and $\mathrm{Sr}$ isotope systematics of the Vindhyan Supergroup, India. Geology, 30, 131-134.

Reymer, A. \& Schubert, G. 1984. Phanerozoic addition rates to the continental crust and crustal growth. Tectonics, 3, 63-77.
RiCHTER, F. M. 1985. Models for the Archean thermal regime. Earth and Planetary Science Letters, 73, 350-360.

RICHTER, F. M. 1988. A major change in the thermal state of the Earth at the Archean-Proterozoic boundary: consequences for the nature and preservation of continental lithosphere. Journal of Petrology, Special Lithosphere Issue, 39-52.

Rino, S., Komiya, T., Windley, B. F., Katayama, I., Motoki, A. \& Hirata, T. 2004. Major episodic increases of continental crustal growth determined from zircon ages of river sands; implications for mantle overturns in the Early Precambrian. Physics of the Earth and Planetary Interiors, 146, 369-394.

RitTs, B. D. \& GRotzinger, J. P. 1994. Depositional facies and detrital composition of the Paleoproterozoic Et-Then Group, NWT, Canada: sedimentary response to intracratonic indentation. Canadian Journal of Earth Sciences, 31, 1763-1778.

Rogers, J. J. W. 1996. A history of continents in the past three billion years. Journal of Geology, 104, 91-107.

Rogers, J. J. W. \& SANTOSH, M. 2002. Configuration of Columbia, a Mesoproterozoic supercontinent. Gondwana Research, 5, 5-22.

Rollinson, H. 2006. Crustal Generation in the Archean. In: Brown, M. \& RUSHMER, T. (eds) Evolution and Differentiation of the Continental Crust. Cambridge University Press, 173.

Roscoe, S. M. 1973. The Huronian Supergroup, a paleoaphebian succession showing evidence of atmospheric evolution. Geological Association of Canada Special Paper, 12, 31-47.

Rose, E. C., McLoughlin, N. \& Brasier, M. D. 2006. Ground truth: the epistemology of searching for the earliest life on Earth. In: SECKBACH, J. (eds) Life as we know it. Cellular Origin, Life in Extreme Habitats and Astrobiology, 10. Springer, Berlin, 259-285.

RouXel, O. J., BEKKER, A. \& EdWARDS, K. J. 2005. Iron isotope constraints on the Archean and Paleoproterozoic ocean redox state. Science, 307, 1088-1091.

RUDNICK, R. L. 1995. Making continental crust. Nature, 378, 571-577.

Rudnick, R. L., GaO, S., Heinrich, D. H. \& Karl, K. T. 2003. Composition of the Continental Crust. Treatise on Geochemistry 3. Pergamon, Oxford, 1-64.

SAGAN, C. \& Mullen, G. 1972. Earth and Mars: evolution of atmospheres and surface temperatures. American Association for the Advancement of Science, 177, 52-56.

Sakurai, R., Ito, M., Ueno, Y., Kitajima, K. \& MARUYAMA, S. 2005. Facies architecture and sequence-stratigraphic features of the Tumbiana Formation in the Pilbara Craton, northwestern Australia: implications for depositional environments of oxygenic stromatolites during the Late Archean. Precambrian Research, 138, 255-273.

SAlminen, J. \& PESONEN, L. J. 2007. Paleomagnetic and rock magnetic study of the Mesoproterozoic sill, Valaam island, Russian Karelia. Precambrian Research, 159, 212-230.

Schidlowski, M., Eichmann, R. \& Junge, C. E. 1975. Precambrian sedimentary carbonates: carbon and oxygen isotope geochemistry and implications for the terrestrial oxygen budget. Precambrian Research, 2 , $1-69$. 
SChneider, D. A., Bickford, M. E., CAnnon, W. F., Schulz, K. J. \& Hamilton, M. A. 2002. Age of volcanic rocks and syndepositional iron formations, Marquette Range Supergroup: implications for the tectonic setting of Paleoproterozoic, iron formations of the Lake Superior region. Canadian Journal of Earth Sciences, 39, 999-1012.

Schubert, G., Stevenson, D. \& Cassen, P. 1980. Whole planet cooling and the radiogenic heat scource contents of the Earth and the Moon. Journal of Geophysical Research, 85, 2531-2538.

Schubert, G., Turcotte, D. L. \& Olson, P. 2001. Mantle Convection in the Earth and Planets. Cambridge University Press.

SeIlacher, A. 2007. The nature of vendobionts. In: VICKERS-RICH, P. \& KomAROWER, P. (eds) The Rise and Fall of the Ediacaran Biota. Geological Society, London, Special Publications, 286, 387-398.

Seilacher, A., Bose, P. K. \& Pfluger, F. 1998. Triploblastic animals more than 1 billion years ago: trace fossil evidence from India. Science, 282, 80-83.

Sengor, A. M. C. \& NATAL'In, B. A. 2001. Rifts of the World. In: ERNST, R. E. \& BUCHAN, K. L. (eds) Mantle Plumes: Their Identification Through Time. Geological Society of America Special Paper, 352, Boulder, Colorado, 389-482.

ShCherbakova, V. V., Lubnina, N. V., ShCherbaKova, V. P., Mertanen, S., Zhidkov, G. V., VASIlieVA, T. I. \& TSEL'MOVICH, V. A. 2008. Palaeointensity and palaeodirectional studies of early Riphaean dyke complexes in the Lake Ladoga region (Northwestern Russia). Geophysical Journal International, 175, 433-448.

Shen, Y., Canfield, D. E. \& Knoll, A. H. 2002. Middle Proterozoic ocean chemistry: evidence from the McArthur Basin, northern Australia. American Journal of Science, 302, 81.

Shen, Y., KNOLL, A. H. \& Walter, M. R. 2003. Facies dependence of sulfur isotopes in a mid-Proterozoic basin. Nature, 423, 632-635.

SHIELDS, G. A. 2007. A normalised seawater strontium isotope curve: possible implications for Neoproterozoic-Cambrian weathering rates and the further oxygenation of the Earth. Earth Discussions, 2, 69-84.

Shields, G. A. \& Kasting, J. F. 2007. Palaeoclimatology: Evidence for hot early oceans? Nature, 447, E1.

ShiELDS, G. \& VeIzER, J. 2002. Precambrian marine carbonate isotope database: Version 1.1. Geochemistry, Geophysics, Geosystems, 3, 1031; doi: 10.1029/ $2001 \mathrm{GC} 000266$.

Shirey, S. B., Kamber, B. S., Whitehouse, M. J., Mueller, P. A. \& BASU, A. R. 2008. A review of the isotopic and trace element evidence for mantle and crustal processes in the Hadean and Archean: implications for the onset of plate tectonic subduction. In: Condie, K. C. \& PeAse, V. (eds) When Did Plate Tectonics Start on Earth. Geological Society of America Special Paper, 440, 1-29.

SILVER, P. G. \& BEHN, M. D. 2008a. Intermittent plate tectonics? Science, 319, 85.

Silver, P. G. \& Behn, M. D. 2008b. Response to Comment on 'Intermittent Plate Tectonics?' Science, 320, $1291 b$.
Simonson, B. M. \& GLAss, B. P. 2004. Spherule layers Records of ancient impacts. Annual Review of Earth and Planetary Sciences, 32, 329-362.

Simonson, B. M., Sumner, D. Y., Beukes, N. J., JOHNSON, S. \& GUTZMER, J. 2009. Correlating multiple Neoarchean-Paleoproterozoic impact spherule layers between South Africa and Western Australia. Precambrian Research, 169, 100-111.

Smirnov, A. V., TARdunO, J. A. \& Pisakin, B. N. 2003. Paleointensity of the early geodynamo $(2.45 \mathrm{Ga})$ as recorded in Karelia: A single-crystal approach. Geology, 31, 415-418.

STERn, R. J. 2005. Evidence from ophiolites, blueschists, and ultrahigh-pressure metamorphic terranes that the modern episode of subduction tectonics began in Neoproterozoic time. Geology, 33, 557-560.

Stevenson, D. J. 1981. Models of the Earth's core. Science, 214, 611-619.

Stevenson, D. J., Spohn, T. \& Schubert, G. 1983. Magnetism and thermal evolution of the terrestrial planets. Icarus, 54, 466-489.

Stockwell, C. H. 1982. Proposals for Time Classification and Correlation of Precambrian Rocks and Events in Canada and Adjacent Areas of the Canadian Shield: Part 1, a Time Classification of Precambrian Rocks and Events. Geological Survey of Canada.

Storey, B. C., Leat, P. T., Weaver, S. D., Pankhurst, R. J., Bradshaw, J. D. \& Kelley, S. 1999. Mantle plumes and Antarctica-New Zealand rifting: evidence from mid-Cretaceous mafic dykes. Journal of the Geological Society, 156, 659-671.

Strik, G., Blake, T. S., Zegers, T. E., White, S. H. \& LANGereis, C. G. 2003. Palaeomagnetism of flood basalts in the Pilbara Craton, Western Australia: late Archaean continental drift and the oldest known reversal of the geomagnetic field. Journal of Geophysical Research, 108, 2551.

SuMnER, D. Y. \& GROTZINGER, J. P. 1996. Were kinetics of Archean calcium carbonate precipitation related to oxygen concentration? Geology, 24, 119-122.

TACKLEY, P. J. 2000. Mantle convection and plate tectonics: toward an integrated physical and chemical theory. Science, $\mathbf{2 8 8}, 2002-2007$.

TACKLEY, P. J. 2008. Geodynamics: Layer cake or plum pudding? Nature Geoscience, 1, 157-158.

TAJIKA, E. 2003. Faint young Sun and the carbon cycle: implication for the Proterozoic global glaciations. Earth and Planetary Science Letters, 214, 443-453.

TAYLOR, S. R. 1964. Abundance of chemical elements in the continental crust: a new table. Geochimica et Cosmochimica Acta, 28, 1273-1285.

TAYLOR, S. R. \& MCLENNAN, S. M. 1985. The Continental Crust: its Composition and Evolution: an Examination of the Geochemical Record Preserved in Sedimentary Rocks. Blackwell Scientific Publications, Oxford.

TAYLOR, S. R. \& MCLEnNAN, S. 1995. The geochemical composition of the continental crust. Reviews in Geophysics, 33, 241-265.

TRAMPERT, J. \& VAN DER HILST, R. D. 2005. Towards a Quantitative Interpretation of Global Seismic Tomography. Geophysical Monograph, American Geophysical Union, 160, 47.

TRENDALL, A. F. 2002. The significance of iron-formation in the Precambrian stratigraphic record. Special 
Publication of the International Association of Sedimentologists, 33, 33-66.

Trindade, R. I. F., D’Agrella-Filho, M. S., Epof, I. \& Brito Neves, B. B. 2006. Paleomagnetism of Early Cambrian Itabaiana mafic dikes (NE Brazil) and the final assembly of Gondwana. Earth and Planetary Science Letters, 244, 361-377.

TUREKIAN, K. K. \& WEDEPOHL, K. H. 1961. Distribution of the Elements in Some Major Units of the Earth's Crust. Geological Society of America Bulletin, 72, $175-192$.

TYLER, S. A. \& BARGHOORN, E. S. 1954. Occurrence of structurally preserved plants in Pre-cambrian rocks of the Canadian Shield. Science, 119, 606-608.

Valentine, J. W. \& Moores, E. M. 1970. Plate-tectonic regulation of faunal diversity and sea level: a model. Nature, 228, 657-659.

VALLEY, J. W., LACKEY, J. S. ET AL. 2005. 4.4 billion years of crustal maturation: oxygen isotope ratios of magmatic zircon. Contributions to Mineralogy and Petrology, 150, 561-580.

VAN DEN BoORN, S. H. J. M., VAN Bergen, M. J., NiJMAN, W. \& VRoon, P. Z. 2007. Dual role of seawater and hydrothermal fluids in Early Archean chert formation: evidence from silicon isotopes. Geology, 35, 939-942.

VAN DER Hilst, R. D., WidiYANTORO, S. \& ENGDAhL, E. R. 1997. Evidence for deep mantle circulation from global tomography. Nature, 386, 578-584.

van Hunen, J., van KeKen, P. E., Hynes, A. \& DAviEs, G. F. 2008. Tectonics of early Earth: some geodynamic considerations. In: CoNDIE, K. C. \& Pease, V. (eds) When Did Plate Tectonics Begin on Planet Earth? The Geological Society of America, Special Paper, 440, 157-172.

van Keken, P. E., Hauri, E. H. \& Ballentine, C. J. 2002. Mantle mixing: the generation, preservation, and destruction of chemical heterogeneity. Annual Review of Earth and Planetary Sciences, 30, 493-525.

Vaughan, A. P. M. \& Storey, B. C. 2007. A new supercontinent self-destruct mechanism: evidence from the Late Triassic-Early Jurassic. Journal of the Geological Society, 164, 383.

VEIZER, J. \& JANSEN, S. L. 1979. Basement and sedimentary recycling and continental evolution. Journal of Geology, 87, 341-370.

Ventura, G. T., Kenig, F. ET AL. 2007. Molecular evidence of Late Archean archaea and the presence of a subsurface hydrothermal biosphere. Proceedings of the National Academy of Sciences, 104, 14260.

Waldb Auer, J. R., Sherman, L. S., Sumner, D. Y. \& Summons, R. E. 2009. Late Archean molecular fossils from the Transvaal Supergroup record the antiquity of microbial diversity and aerobiosis. Precambrian Research, 169, 28-47.

WAlter, M. R., Du, R. \& Horodyski, R. J. 1990. Coiled carbonaceous megafossils from the Middle Proterozoic of Jixian (Tianjin) and Montana. American Journal of Science, 290, 133-148.

WALZER, U. \& HENDEL, R. 2008. Mantle convection and evolution with growing continents. Journal of Geophysical Research-Solid Earth, 113, B09405.

Wardle, R. J., James, D. T., ScotT, D. J. \& Hall, J. 2002. The southeastern Churchill Province: synthesis of a Paleoproterozoic transpressional orogen. Canadian Journal of Earth Sciences, 39, 639-663.

Westall, F. 2009. Life on an anaerobic planet. Science, 323, 471 .

Whittington, A. G., Hofmeister, A. M. \& NabeleK, P. I. 2009. Temperature-dependent thermal diffusivity of the Earth's crust and implications for magmatism. Nature, 458, 319-321.

Wille, M., Kramers, J. D. ET AL. 2007. Evidence for a gradual rise of oxygen between 2.6 and $2.5 \mathrm{Ga}$ from Mo isotopes and Re-PGE signatures in shales. Geochimica et Cosmochimica Acta, 71, 2417-2435.

Williams, G. E. 2000. Geological constraints on the Precambrian history of Earth's rotation and the moon's orbit. Reviews of Geophysics, 38, 37-59.

WiLliams, G. E. 2005. Subglacial meltwater channels and glaciofluvial deposits in the Kimberley Basin, Western Australia: $1.8 \mathrm{Ga}$ low-latitude glaciation coeval with continental assembly. Journal of the Geological Society, 162, 111-124.

Williams, H., HofFman, P. H., Lewry, J. F., Monger, J. W. H. \& Rivers, T. 1991. Anatomy of North America: thematic geologic portrayals of the continents. Tectonophysics, 187, 117-134.

Wingate, M. T. D. 1998. A palaeomagnetic test of the Kaapvaal - Pilbara (Vaalbara) connection at $2.78 \mathrm{Ga}$. South African Journal of Geology, 101, 257-274.

Wingate, M. T. D., Pisarevsky, S. A., Gladkochub, D. P., Donskaya, T. V., Konstantinov, K. M., Mazukabzov, A. M. \& Stanevich, A. M. 2009. Geochronology and paleomagnetism of mafic igneous rocks in the Olenek Uplift, northern Siberia: implications for Mesoproterozoic supercontinents and paleogeography. Precambrian Research, 170, $256-266$.

WISE, D. U. 1974. Continental margins, freeboard and the volumes of continents and oceans through time. In: BurK, C. A. \& Drake, C. L. (eds) The Geology of Continental Margins. Springer, New York, 45-58.

Worsley, T. R., Nance, D. \& Moody, J. B. 1984. Global tectonics and eustasy for the past 2 billion years. Marine Geology, 58, 373-400.

Zahnle, K., Claire, M. \& Catling, D. 2006. The loss of mass-independent fractionation in sulfur due to a Palaeoproterozoic collapse of atmospheric methane. Geobiology, 4, 271-283.

ZANG, W. L. 2007. Deposition and deformation of late Archaean sediments and preservation of microfossils in the Harris Greenstone Domain, Gawler Craton, South Australia. Precambrian Research, 156, $107-124$.

Zegers, T. E., DE Wit, M. J., DAnN, J. \& White, S. H. 1998. Vaalbara, Earth's oldest assembled continent? A combined structural, geochronological, and palaeomagnetic test. Terra Nova, 10, 250-259.

Zhao, G. C., Cawood, P. A., Wilde, S. A. \& Sun, M. 2002. Review of global $2.1-1.8 \mathrm{Ga}$ orogens: implications for a pre-Rodinia supercontinent. Earth Science Reviews, 59, 125-162.

Zhao, G., Sun, M., Wilde, S. A. \& LI, S. 2004. A paleomesoproterozoic supercontinent: assembly, growth and breakup. Earth Science Reviews, 67, 91-123. 